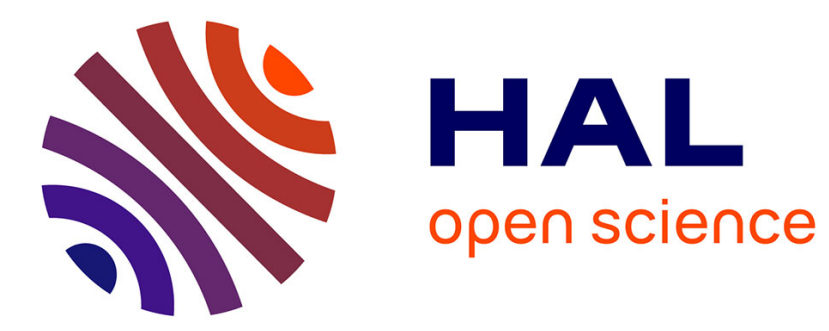

\title{
Biogeochemistry of fatty acids in a river-dominated Mediterranean ecosystem (Rhône River prodelta, Gulf of Lions, France): Origins and diagenesis
}

\author{
Audrey M. Pruski, Roselyne Buscail, Solveig Bourgeois, Gilles Vétion, \\ Jennifer Coston-Guarini, Christophe Rabouille
}

\section{To cite this version:}

Audrey M. Pruski, Roselyne Buscail, Solveig Bourgeois, Gilles Vétion, Jennifer Coston-Guarini, et al.. Biogeochemistry of fatty acids in a river-dominated Mediterranean ecosystem (Rhône River prodelta, Gulf of Lions, France): Origins and diagenesis. Organic Geochemistry, 2015, 83-84, pp.227-240. 10.1016/j.orggeochem.2015.04.002 . hal-01148376

\section{HAL Id: hal-01148376 https://hal.sorbonne-universite.fr/hal-01148376}

Submitted on 4 May 2015

HAL is a multi-disciplinary open access archive for the deposit and dissemination of scientific research documents, whether they are published or not. The documents may come from teaching and research institutions in France or abroad, or from public or private research centers.
L'archive ouverte pluridisciplinaire HAL, est destinée au dépôt et à la diffusion de documents scientifiques de niveau recherche, publiés ou non, émanant des établissements d'enseignement et de recherche français ou étrangers, des laboratoires publics ou privés. 
Biogeochemistry of fatty acids in a river-dominated Mediterranean ecosystem (Rhône River prodelta, Gulf of Lions, France): origins and diagenesis

Audrey M. Pruski ${ }^{\mathrm{a}, \mathrm{b}, *}$, Roselyn Buscail ${ }^{\mathrm{c}, \mathrm{d}}$, Solveig Bourgeois ${ }^{\mathrm{a}, \mathrm{b}, 1}$, Gilles Vétion ${ }^{\mathrm{a}, \mathrm{b}}$, Jennifer Coston-Guarini ${ }^{\mathrm{e}, 2}$, Christophe Rabouille ${ }^{\mathrm{f}}$

${ }^{a}$ Sorbonne Universités, UPMC Univ Paris 06, UMR 8222, LECOB, Observatoire Océanologique, Banyuls-sur-Mer, France

${ }^{\mathrm{b}}$ CNRS, UMR 8222, LECOB, Observatoire Océanologique, Banyuls-sur-Mer, France

${ }^{\mathrm{c}}$ CNRS, Centre de Formation et de Recherche sur les Environnements Méditerranéens, UMR 5110, F-66860, Perpignan, France

${ }^{\mathrm{d}}$ Université Perpignan Via Domitia, Centre de Formation et de Recherche sur les Environnements Méditerranéens, UMR 5110, F-66860, Perpignan, France

${ }^{\mathrm{e}}$ UPMC, Université Paris 06, 4 Place Jussieu, 75252 Paris, France

${ }^{\mathrm{f}}$ Laboratoire des Sciences du Climat et de l'Environnement, UMR 8212 CEA-CNRS-UVSQ et IPSL, Av de la Terrasse, 91190 Gif sur Yvette, France

* Corresponding author: A. M. Pruski, Observatoire Océanologique de Banyuls, 1 avenue du Fontaulé, 66650 Banyuls sur mer, France. Tel : 003346888 73 79, Fax : 00334688873 95, email : audrey.pruski@obs-banyuls.fr

1 Present address: University of Aberdeen, Oceanlab, Newburgh, Aberdeenshire AB41 6AA, UK.

2 Present address: UMR6539, UBO-CNRS-IRD, Laboratoire de l'Environnement Marin 
(LEMAR), Institut Universitaire Européen de la Mer, Technopôle Brest Iroise, Place Nicolas Copernic, 29280 Plouzané, France.

\section{ABSTRACT}

Major rivers transfer high loads of continental particulate organic matter to deltaic environments, where the impact on the biogeochemistry and productivity of coastal sediments depends on the sources and lability of these inputs. Our aims are to provide new insights into the reactivity of riverine inputs in coastal environments and to delineate the parameters controlling their fate in these dynamic systems. Sediment cores were collected from a Mediterranean deltaic system (the Rhône prodelta and its adjacent shelf) during a period of moderate river discharge (Spring 2007) and analyzed for their fatty acid composition. Sediment properties were also described using biochemical bulk analyses (organic carbon and lipids), granulometry and profiles of redox potential. Based on the bulk compositional changes and hierarchical clustering of the fatty acid biomarkers, we determined the principal sources of organic matter and their spatial distribution. Fatty acids were primarily of continental origin in the prodelta, shifting to a higher contribution from marine sources in the shelf area. Fatty acids derived from both continental and marine sources were efficiently degraded in the sediments by microbial decay processes in the upper oxic layer. Degradation rate constants calculated from the down-core decreases in concentrations indicate that fatty acid degradation was enhanced in sediments influenced by the Rhône River. The most important parameters affecting fatty acid preservation were the inherent stability of individual molecular components and their physical association with mineral matrices, the source and freshness of the inputs, and the depositional environment (redox condition, accumulation rates). 
Keywords

Mediterranean Sea, ocean margin, Rhône River, fatty acid biomarkers, lipid biogeochemistry, redox condition, early diagenesis 


\section{Introduction}

Burial in ocean sediments is the ultimate fate for the land-derived organic matter (OM) that escapes remineralization in continental reservoirs (Hedges et al., 1997). It is estimated that $250 \mathrm{Tg}$ of carbon arrive annually in coastal oceans (McKee et al., 2004) and rivers represent the major route of export for terrestrial particulate organic matter (POM) to the sea. Through flocculation and aggregation processes occurring in the water column most of this particulate input settles close to shore. Rivers also deliver large amounts of dissolved organic carbon (DOC) and nutrients that stimulate local primary productivity, contributing further to the flux of particulate organic carbon (POC) reaching the seafloor (Eadie et al., 1994). Ultimately less than $50 \%$ of the terrestrial organic carbon delivered by rivers is preserved in marine systems, and as much as $80 \%$ of this amount is trapped in continental margin sediments (for reviews see Hedges et al., 1997; Burdige, 2007). These rough calculations challenge commonly held assumptions about the refractory nature of terrestrial OM reaching the marine environment. While it is true that terrestrial $\mathrm{OM}$ is generally more resistant to degradation than recently synthesized marine OM (Aller, 1998), river biogenic inputs derive from a wide variety of allochthonous sources, each of which differ in their specific reactivities. For example, soil-derived OM, which accounts for most fluvial inputs, is relatively refractory (Burdige, 2007), but non negligible amounts of labile POC (such as freshwater phytoplankton) are also transported by large rivers to deltaic settings, and the relative proportions of these different sources vary with discharge conditions and the season (Mayer et al., 2008; Harmelin-Vivien et al., 2010).

Detrital OM is a complex mixture of macromolecules including labile components derived from fresh plant materials (pigments, proteins, sugars, lipids), refractory substances (like 
lignin) and recalcitrant $\mathrm{OM}$ produced during humification. After deposition, the persistence of a particular organic molecule in the sediment matrix depends on its intrinsic reactivity and resistance to microbial degradation (Sun and Wakeham, 1994). Labile compounds degrade rapidly in upper sediment layers, so that the refractory substances increase proportionally with depth. Organic matter preservation is impacted by any condition affecting the efficiency and types of bacterial remineralization processes. Aerobic degradation is generally faster than anaerobic degradation (Harvey et al., 1995; Sun et al., 1997; Dauwe et al., 2001; Ding and Sun, 2005), and burial rates are inversely related to the length of time the organic matter is exposed to pore-water molecular oxygen (Burdige, 2007).

Mediterranean rivers show some of the highest sediment yields in the world, taking into account the size of their watershed and mean annual solid discharge (AQUASTAT compilation, 2014), thus playing a disproportionate role in the export of POC to the coastal zone. Since the construction of the Aswan Dam on the Nile River in the 1960s, the Rhône River has become the most important source of freshwater and sediment to the Mediterranean Sea with about $80 \%$ of the terrestrial discharge being delivered during large flood events whose frequency is rising (Antonelli et al. (2008) counted 7 events in the decade preceding their paper). The quality of the riverine inputs is expected to have a profound impact on the fate of terrestrial OM in nearshore sediments from dynamic environments (McKee et al., 2004). We previously investigated the distribution and chemical composition of land-derived OM in surface sediments from the Rhône River prodelta region of the Gulf of Lions (western Mediterranean Sea) during the research project CHACCRA (Climate and Human-induced Alterations in Carbon Cycling at the RiverseA connection). By using complementary bulk and molecular markers, we have shown that the Rhône River inputs are relatively labile and of good nutritional quality for benthic invertebrates 
(Bourgeois et al., 2011). An offshore gradient for organic matter decay occurs in surface sediments, probably reflecting the rapid deposition of the terrigenous POC in the prodelta and some mixing with fresh autochthonous material. In a deltaic environment, where the organic matter derives from a mixture of different sources, information on the origin and diagenesis of sedimentary OM is particularly important for understanding the role(s) of different ecological and geochemical processes involved in carbon cycling. As such, specific lipids like fatty acids, which are part of the pool of labile OM, can provide details about the origin and reactivity of organic matter under different conditions along this offshore depositional and diagenetic gradient. In the present study, we thus focused more thoroughly on the origin and degradation history of sedimentary fatty acids off the Rhône River mouth.

\section{Materials and Methods}

\subsection{Regional setting and sampling strategy}

The Rhône River has one of the largest catchment basins in Europe and accounts for 80\% of the terrigenous material supply to the Gulf of Lions (Aloisi et al., 1977). Close to the river mouth, fluvial particulate inputs rapidly settle to form a large, wave-dominated, deltaic system characterized by thick deposits of fine-grained sediments. Indeed, $75 \%$ of the suspended matter of the Rhône River is deposited within three miles of the river mouth (Aloisi et al., 1979). The prodelta area $\left(\sim 30 \mathrm{~km}^{2}\right)$ cannot be considered a permanent repository for these terrestrial inputs because intensive sediment reworking occurs at these shallow depths through resuspension events and erosion phases (Marion et al., 2010). Nutrient inputs from the Rhône River also create a locally productive environment in comparison to the general oligotrophic condition of the Mediterranean Sea. 
The study area is located inside a $25 \mathrm{~km}$ radius off the Rhône River (Fig. 1). Sampling took place during a period of moderate river runoff (April 2007) and followed a small flood event in the northern tributaries that ended 10 days before. The spatial survey of Bourgeois et al. (2011) revealed a large compositional gradient along the river mouth-shelf transect in April 2007 that was well characterized by a six-fold decrease of the fatty acid concentrations. Based on these previous results, five stations with a large range of depositional settings (Fig. 1, Table 1) were selected for studying the down-core distribution of sedimentary OM. Four stations are located along the main direction of the dilution plume ( $\mathrm{A}$ and $\mathrm{B}$ in the prodelta area, $\mathrm{C}$ and $\mathrm{F}$ on the adjacent shelf). One station is more eastward and is referred to throughout the text as the "marine reference" (station "J", outside of the Rhône River influence). Considering the low, within site heterogeneity and the marked difference between stations, we are confident that the selected cores are representative of the five settings.

Sediment cores were collected using a multicorer MUC 8/100 (Oktopus GmbH) during the RioMAr 1 cruise. Three cores per station were sliced into seven horizontal layers $(0-0.5$, $0.5-1,1-2,2-3,3-5,5-7$ and $7-10 \mathrm{~cm})$ and each sediment layer was carefully homogenized. An aliquot was immediately frozen at $-20{ }^{\circ} \mathrm{C}$ for bulk analyses, and the remaining sediments were rapidly desalted before freezing at $-20{ }^{\circ} \mathrm{C}$.

\subsection{Physico-chemical and bulk characteristics}

Sediment grain size distributions were determined on a Malvern Mastersizer 2000 laser diffractometer and classified using the Wentworth scale. Vertical profiles of oxidation-reduction potential $(\mathrm{Eh}$ in $\mathrm{mV})$ in the sediment were done on one core at each station using a $\mathrm{pH}$ meter (platinum electrode: $\mathrm{Pt} / \mathrm{Ag} / \mathrm{AgCl}$ ) immediately after multi-corer sampling. Readings were first 
recorded from the electrode inserted vertically into the upper $5 \mathrm{~mm}$ of each core, and then electrodes were inserted horizontally every $2 \mathrm{~cm}$ along the full core length through pre-drilled holes in the core tubes. These cores were also used to describe the sedimentary facies.

Organic carbon (OC) concentrations were measured at each station from the 7 horizontal layers of sediments ( 3 cores per station). For OC determinations, freeze-dried subsamples were acidified with $2 \mathrm{M} \mathrm{HCl}$ (overnight at $50{ }^{\circ} \mathrm{C}$ ) to remove carbonates (Cauwet et al., 1990). Analyses were then done using an automated CN-analyzer LECO 2000. The precision for all OC measurements was $\pm 2 \%$.

Total lipids were measured on one core per station (i.e. core \#1) by a colorimetric method (Barnes and Blackstock, 1973) after extraction with a 2:1 (v:v) $\mathrm{CHCl}_{3}-\mathrm{MeOH}$ mixture. Absorption of the products was measured at $520 \mathrm{~nm}$ with a Beckman UV spectrophotometer (precision of $\pm 10 \%$ ).

\subsection{Fatty acid analysis}

Fatty acid analyses were performed on the same cores as for total lipids. Sedimentary fatty acids were analyzed by GC-MS after derivatization to the corresponding methyl esters (FAME) on approximately $1.5 \mathrm{~g}$ of freeze-dried sediment. The procedure was previously described in Bourgeois et al. (2011) and used a hot $\mathrm{CHCl}_{3}-\mathrm{MeOH}-\mathrm{H}_{2} \mathrm{SO}_{4}$ solution to digest particulate OM, extract lipids, release fatty acids from lipids and simultaneously convert them to fatty acid methyl esters (FAMEs). FAMEs were analyzed on a gas chromatograph (Varian 3900) fitted with a Saturn 2100T ion trap detector (Varian) and quantified as described in Bourgeois et al. (2011). Structural assignments were confirmed using the NIST library. Fatty acid concentrations in the sediments were expressed as weight per dry weight sediment $(\mu \mathrm{g} / \mathrm{g} \mathrm{DW})$ or 
as percentages. Repeatability of the analysis, determined by comparing relative standard deviations of 41 fatty acids in six different preparations of our standard solution, ranged from 1.0 to $5.4 \%$ with a mean value of $2.4 \%$.

\subsection{Data presentation and statistical analysis}

Fatty acid concentrations (initially in $\mu \mathrm{g} / \mathrm{g} \mathrm{DW}$ ) were normalized to OC to remove the dilution effect of the mineral matrix. The fatty acid terminology used here is expressed as ' $\mathrm{X}: \mathrm{Y} \omega \mathrm{Z}$ ', where ' $\mathrm{X}$ ' indicates the total number of carbons, ' $\mathrm{Y}$ ' the number of double bonds and ' $\omega Z$ ' indicates the number of carbon atoms between the closest double bond and the aliphatic end of the molecule. For the down-core analysis of fatty acids, compounds were grouped as follows: the mid-chain even-number saturated fatty acids (MC-SAFAs, $<\mathrm{C}_{20}$ ) of mixed origin, the terrestrial long-chain saturated fatty acids (LC-SAFAs, $\geq \mathrm{C}_{20}$ ), the terrestrial $\mathrm{C}_{18}$ polyunsaturated fatty acids ( $\mathrm{C}_{18}$-PUFAs, $18: 2 \omega 6$ and 18:3 $\left.\omega 3\right)$, the remaining PUFAs attributed to microalgae, the monounsaturated fatty acids (MUFAs) dominated by two bacterial compounds of the $\omega 7$ series $\left(\mathrm{C}_{16}\right.$ and $\left.\mathrm{C}_{18}\right)$, and the straight and branched odd-numbered fatty acids of bacterial origin (BACT; Table 2).

Because some variables were not normally distributed even after data transformation, we applied Spearman rank order correlations to explore relationships among molecular markers and physical conditions.

Fatty acid data were analyzed using hierarchical clustering to determine groups of fatty acids that co-vary within the 35 samples (dataset in Supplementary information, Table S1). Three fatty acids $(10: 0,18: 4 \omega 3,20: 1 \omega 9)$ were removed from the dataset prior to analysis as they were only found in trace amounts and in a few samples. Percentages were then recalculated on 
the 25 remaining fatty acids and a centered log-ratio transformation for compositional data was applied (Aitchison, 2003). The multivariate normality of the transformed data was confirmed using Mardia's multivariate skewness and kurtosis measurements, with tests based on chisquared (skewness) and normal (kurtosis) distributions. The fatty acid data were then autoscaled (mean centered and divided by the standard deviation of each variable). Following these transformations, we performed a hierarchical clustering analysis (HCA) using Euclidean distance and Ward's aggregation (Martín-Fernández et al., 1998). Ward's method was selected because it joined clusters such that within-group variance is minimized (Ward, 1963). Compounds that share a similar pattern of distribution have a high degree of similarity and cluster together (Ali and Mudge, 2006). A K-means clustering followed by a non-parametric multidimensional scaling (MDS) was also carried out to confirm the grouping obtained by the HCA (unpublished data).

Spearman correlations were calculated with XLSTAT, log-ratio transformations were done with CoDaPack 2.01 software, whereas Shapiro's test of normality, Mardia's multivariate tests and the clustering analyses were performed with R software.

\subsection{Calculation of degradation rate constants}

The fate of fatty acids in bioturbated sediments can be described using a transportreaction model at steady-state following the approach of Berner (1980) as expanded by Niggemann and Schubert (2006). This approach considers two pools of fatty acids: a labile fraction rapidly degraded in the upper sediments and a refractory fraction resistant to degradation. In the model, the transport of particles carrying fatty acids is described by sedimentation and bioturbation, while degradation is the result of the bacterial decomposition of 
fatty acids. The calculation assumes steady state conditions, including a constant flux of fatty acids from the overlying water. The model is written as:

$D_{b} \frac{d^{2} C}{d z^{2}}-\omega \frac{d C}{d z}-k C=0$ (Equation 1$)$

Where $\mathrm{C}$ is the individual fatty acid compound concentration $(\mu \mathrm{g} / \mathrm{g} \mathrm{DW})$ at a depth $\mathrm{z}$ in the sediment $(\mathrm{cm}), D_{b}$ is the bioturbation coefficient $\left(\mathrm{cm}^{2} / \mathrm{a}\right), \omega$ is the sedimentation rate $(\mathrm{cm} / \mathrm{a})$ and $\mathrm{k}$ is the mineralization rate constant of the labile pool of fatty acids $\left(\mathrm{a}^{-1}\right)$.

The solution of equation 1 is:

$$
C=C_{0} e^{(-\alpha \mathrm{z})}+C_{r e f} \text { and } \alpha=\frac{-\omega+\sqrt{\omega^{2}+4 \mathrm{k} \mathrm{D}_{b}}}{2 D_{b}}
$$

Where $\mathrm{C}_{0}$ is the concentration of the labile fraction of the compound at the sedimentwater interface and $\mathrm{C}_{\text {ref }}$ is the concentration at a depth below which the distribution reaches a stable concentration corresponding to the refractory pool.

Values of the degradation rate constant $(\mathrm{k})$ were calculated by fitting the model output to the observed data. We minimized the distance between the values measured in discrete sediment layers and the model solution integrated over the thickness of the layers. This procedure turned out to be very close to a simple curve to data distance at mid-depth of the discrete interval, but the procedure we used is more sound especially when there are large composition gradients as those observed near the sediment-water interface. Indeed, it compares the model outputs calculated as integrated over sampling depth to the actual measurement (which is also an integral over the sampling thickness).

The calculation of $\mathrm{k}$ values requires information about $\mathrm{Db}$ and $\omega$; we used values for these parameters given in a recent study on the recycling of organic matter at the same stations (Pastor et al., 2011; see Table 1 for values used). 


\section{Results and Discussion}

\subsection{Influence of a typical Mediterranean deltaic system on sedimentary organic matter distribution}

More than one hundred moderate to small, recent (> 5000 years age) deltas have been identified on the Mediterranean coastal margins (Stanley, 1997). As one of the four largest depocenters in the Mediterranean Sea, the Rhône deltaic-shelf region represents a model environment to study the biogeochemical fate of river-borne biogenic inputs in modern deltaic systems.

\subsubsection{Sedimentological, geochemical and redox conditions}

In high energy, wave-dominated deltas, the deceleration of river flow and the flocculation induced by mixing processes at the freshwater/salt transition result in the deposition of most of the sediment load close to the shoreline (i.e. in the prodelta area). The typical grain-size distribution observed begins with predominantly sand and silt size particles accumulating near sea level and the river mouth to fine clays deposited farther offshore (Fig. 2). As expected, finegrained sediments $(<63 \mu \mathrm{m})$ prevailed in the study area and their contribution increased from the Rhône River mouth to the shelf area (average proportions of $<63 \mu \mathrm{m}$ sediment for the entire cores were: station A, $\sim 68 \%$; station B, $87 \%$; seaward, > 94\%; Fig. 2). At station A in the prodelta, sediments were characterized by a coarser sandy fraction accounting for $26 \%$ to $35 \%$ of the matrix. This coarser material was slightly more apparent in the surficial deposits $(0-0.5 \mathrm{~cm}$; visual observation). Fine silts were predominant $(\geq 50 \%)$ at all other stations and muddy sediments were homogenously distributed over the $10 \mathrm{~cm}$ length of the cores (Fig. 2). 
Based on visual inspection, we identified four sedimentary facies (Fig. 3) whose distributions were consistent with the redox potential values (Eh) recorded. Considering these Eh values, oxidized conditions were restricted to surficial deposits (the $0-0.5 \mathrm{~cm}$ layer) in the vicinity of the river mouth, extended down to $2 \mathrm{~cm}$ depth at $22 \mathrm{~km}$ offshore (station $\mathrm{F}$ ), and down to $4 \mathrm{~cm}$ depth at the reference station $(\mathrm{J})$ (Table 1). Oxygenation penetration depths followed the same pattern as the redox potential discontinuity (from $1.4 \mathrm{~mm}$ at station A to $9.7 \mathrm{~mm}$ at station F; Table 1). In the reduced sediments, dark spots visible in the sedimentary sequences indicated sulfate reduction of organic matter was occurring. With the exception of station A which is near the river mouth, signs of bioturbation were visible on sediment profile images (Labrune et al., 2012). Overall, redox conditions and sediment oxygenation strongly determined faunal disturbance of the sediments, and accordingly lower bioturbation rates $\left(D_{b}\right)$ were observed in reduced and poorly oxygenated nearshore sediments and higher benthic activity in more oxidized shelf sediments (Table 1).

As the Rhône influence lessens seaward the amount of organic carbon decreased in the surficial sediments (from $1.9 \%$ nearshore to $1 \% \mathrm{DW}$ in the $0-0.5 \mathrm{~cm}$ layers seaward and at the marine reference site; Fig. 4A). No down-core trend was observed within these cores, except at station A where discrete sub-surface organic rich sediment layers were observed. Generally, total lipid analyses mirrored patterns already seen with the OC content. For example, total lipids ranged from 0.47 to $1.09 \mathrm{mg} / \mathrm{g} \mathrm{DW}$ in the surficial deposits with a trend for decreasing values seaward, following the diminution in organic carbon. However, once normalized to the OC content, lipid yields were similar for the surface sediments of all stations (47 to $63.7 \mathrm{mg} / \mathrm{g} \mathrm{OC}$ ) and exhibited sub-surface maxima (Fig. 4B).

Thus, as expected, the amounts of carbon available in the sediments decreased and the 
conditions in the sediments were more oxidizing as distance offshore increased. This pattern can also be observed for the more labile fraction of the organic matter: the fatty acids (Fig. 4C). High OC-normalized total fatty acid (TFA) concentrations are commonly found in shallow areas where little degradation occurs prior to deposition (Venturini et al., 2012). At the study sites, OC-normalized TFA concentrations in the surficial sediments were high in the prodelta area and decreased along the SW transect (from 8.0 to $2.8 \mathrm{mg} / \mathrm{g} \mathrm{OC}$ ). A similar TFA distribution has been observed in other river ocean dominated margins, such as off the Mississippi River where concentrations ranging from 1.8 to $8.3 \mathrm{mg} / \mathrm{g}$ OC were reported with a significant enrichment in fatty acids in sediments from the shelf area (25-87 $\mathrm{m}$ water depth) compared to the adjacent slope (Waterson and Canuel, 2008).

\subsubsection{Organic matter sources inferred from biomarkers}

Based on $\delta^{13} \mathrm{C}$ values (Table 1), sedimentary $\mathrm{OM}$ in the vicinity of the Rhône River is almost exclusively from terrestrial sources (up to 97\%; for a description of the binary mixing model used for these calculations see Bourgeois et al., 2011), whereas outside the area situated directly under the influence of the Rhône River, the organic matter is composed of marine and riverine sources in nearly equal amounts (terrestrial contribution: 57 and 59\% at stations $\mathrm{F}$ and $\mathrm{J}$, respectively).

Lipid biomarkers, and in particular fatty acids, furnish complementary information about the source and quality of the organic matter. Source assignments were made based on literature values, specific results for selected Mediterranean sources (Table 2) and hierarchical cluster analysis. This a posteriori approach discriminates groups of compounds with similar distribution patterns, i.e. those originating from the same sources (Fig. 5). This method identified four 
distinct clusters separating the fatty acids prevalent in the terrestrial OM delivered by the Rhône River (G3\&4) and those associated with decaying phytoplankton having freshwater and marine origins (G1\&2). The composition of these four groups was further confirmed by a K-means cluster procedure (data not shown).

The HCA identified two groups of fatty acid markers deriving from terrestrial inputs (G3\&4, Fig. 5). These well-defined clusters may highlight two different sources of higher plant detritus or different susceptibilities of these terrestrial markers to degradation. The $\mathrm{C}_{20}, \mathrm{C}_{22}$ and $\mathrm{C}_{23}$ saturated fatty acids (20:0, 22:0 and 23:0) predominated over their longer chain homologues $\left(\geq \mathrm{C}_{24}\right)$ with a net dominance of $\mathrm{C}_{22}$. These compounds are less frequent in the plant kingdom than the short chain saturated fatty acids, but can be important in the seeds, flowers or leaves of some plants (Gunstone et al., 2007; Barros et al., 2010). For example, $\mathrm{C}_{22}$ accounts for up to $25 \%$ of the fatty acids in some species of plants from European herbaceous communities (Ferreira et al., 2011). In the present study, they accounted for $\sim 9$ to $16 \%$ of the fatty acid pool in the riverine suspended OM, Mediterranean oak leaves and macrodetritus (Table 2). This range of values is quite similar to their proportion in the surface sediments at stations under the Rhône River influence $(\sim 11 \%$ at $\mathrm{A}$ and $\mathrm{B})$. The contribution of these fatty acids decreased in the surface sediments down to $\sim 5 \%$ at the offshore and reference stations ( $\mathrm{F}$ and $\mathrm{J})$, consistent with a terrestrial origin. Very long-chain saturated fatty acids $\left(\geq \mathrm{C}_{24}\right)$ are typical of higher plant leaf waxes (Wannigama et al., 1981; Meyers, 1997) and commonly considered indicative of vascular plant materials (Table 2). They represented from $\sim 4$ to $\sim 10 \%$ of the fatty acid pool with a predominance of 24:0 over 26:0 and 28:0. From the proportion of $\mathrm{C}_{24}$ relative to $\mathrm{C}_{22+26}$ saturated fatty acids, it appears that $\mathrm{C}_{3}$ plants predominate over $\mathrm{C}_{4}$ plants (carboxylic acid ratio $>0.67$ for $\mathrm{C}_{3}$ plants; Wiesenberg and Schwark, 2006) which is also consistent with the bulk $\delta^{13} \mathrm{C}$ analyses 
(Bourgeois et al., 2011). Suspended OM from the Rhône River contained nearly 2\% of 30:0, but this compound was only present in trace amounts in the sediments probably because of dilution with the inorganic matrix or heterogeneous distribution within the sediments.

A trend of lower carbon-normalized yields of higher plant biomarkers (LC-SAFAs) was observed with distance from the river mouth, consistent with their terrestrial origin and the retention of coarse-sized particles and plant debris within the prodelta as a consequence of lateral hydrodynamic sorting (Tesi et al., 2007). Two other terrestrial biomarkers (linoleic acid = 18:2 $\omega 6$ and $\alpha$-linolenic acid $=18: 3 \omega 3$ ) clustered in G3. These $\mathrm{C}_{18}$ PUFAs are often cited as characteristic of halophytes (Meziane et al., 1997), but they are actually abundant in all green leafy plants (Viano et al., 1995) where they may account for a non-negligible fraction of the fatty acids (i.e. $\sim 19 \%$ of the fatty acid pool in oak leaves, $\sim 57 \%$ in duckweeds; Table 2). Despite the predominance of fatty acids deriving from higher plants in cluster G3, some evidence for minor contributions from freshwater microeukaryotes is suggested by the higher proportion of DHA

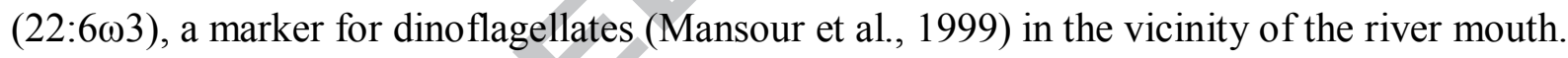
The occurrence of terrestrial makers in sediments from the marine reference site is noteworthy as it suggests the inputs from other continental sources (aeolian dust, other rivers) or occasional intrusions of the Rhône River plume.

The other two groups evidenced in the HCA consist of bacterial, phytoplankton and unspecific fatty acids. The clustering of bacterial markers in G2 along with even numbered saturated fatty acids (12:0, 16:0 and 18:0) is consistent with the existence of a pool of degraded material derived from the water column. Significant amounts of bacteria-specific fatty acids were found at all sites and sediment depths, and indicate the presence of living benthic bacteria or decaying bacterial material. High percentages of monounsaturated fatty acids $(16: 1 \omega 7+18: 1 \omega 7$, 
10-24\%) suggest high inputs from Proteobacteria (for review see Mrozik et al., 2014), which is consistent with pyrosequencing data showing that OTUs from this phylum dominate in sediments from the prodelta (Fagervold et al., 2014). The branched forms, anteiso- and iso-15:0 (ai15:0 and i15:0), were dominant over their straight chain $C_{15}$ homologue. Together with 17:0 and 18:1 $\omega 9$, they are characteristic of the occurrence of Gram-positive bacteria (Mrozik et al., 2014), but branched 15:0 fatty acids may also be abundant in Gram-negative sulfate-reducing bacteria such as Desulfovibrio (Vainshtein et al., 1992). These fatty acids were clustered together with 14:0, suggesting a bacterial source for this non-specific compound, since 14:0 may also be abundant in certain cyanobacteria (Mrozik et al., 2014). This suite of markers were not only found in the offshore stations, but also in the suspended OM delivered by the Rhône River. This observation and the shift in the $\delta^{13} \mathrm{C}$ signature of these molecules along the southwestern transect (Bourgeois et al., 2011) suggest a dual provenance, both freshwater and marine, for this degraded organic matter.

Sediments also received some inputs from fresh phytoplankton as evidenced by the presence of PUFAs produced by microalgae (clustered in G1 and G2). These markers made relatively low contributions to the fatty acids in the sediments, which is consistent with previous studies highlighting the limited exchanges between the water column and the benthic boundary layer in this part of the Gulf of Lions (Naudin et al., 1997). At the uppermost distal station (F), sediments were enriched in lipids compared to the other stations, suggesting a contribution from a fresh marine source (Fig. 4B). In particular, surface sediments at this station were enriched in eicosapentaenoic acid (20:5 03 = EPA), a typical marker of diatoms, and arachidonic acid

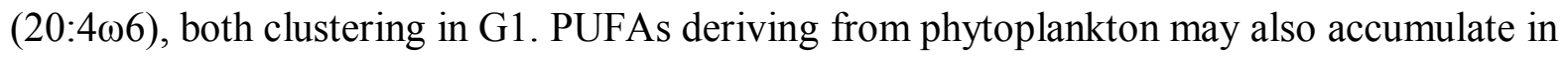
zooplankton through trophic transfer (as seen in Table 2 with the high contribution of PUFAs in 
copepods) and sediment to the seafloor after the death of the animals.

\subsection{Parameters controlling early diagenesis of lipid compounds}

Along a fairly short seaward transect from the river mouth, the rapid decrease of the riverine POC inputs is associated with a marked drop in the quality of the material that settles and profound modifications of the physico-chemical characteristics. We can now consider compositional changes of the organic pool in the sedimentary column in light of all the physical, chemical and biological parameters reported both here and in other CHACCRA program investigations carried out concurrently in the same area (Table 1).

\subsubsection{Evidence of microbial degradation of labile organic matter}

Both terrestrial and marine OM sources were already degraded prior to deposition based on the high proportion of degradation pigments measured in the surficial deposits and the Dauwe's degradation index values (Table 1 for pigments and Bourgeois et al., 2011 for Dauwe index, $0.10 \pm 0.16$ to $-0.44 \pm 0.24$ ). Furthermore, fatty acids accounted for a small fraction of the total lipids with a contribution ranging from $16.2 \%$ in nearshore surface sediments to $2 \%$ of the lipids for the shelf and reference stations. Considering that fatty acids are among the most labile lipid molecules, this trend highlights the increased degradation state of the particulate inputs with distance from the Rhône mouth.

Bacterial remineralization of organic matter in the sediments was considerably enhanced in the prodelta area in comparison to the shelf as shown by the higher rates of diffusive $\mathrm{O}_{2}$ uptake (DOU; Table 1). A positive correlation between the DOU measured during the RIOMAR 1 field campaign (presented in Cathalot et al., 2010) and total fatty acid concentrations (see 
Bourgeois et al., 2011 for results on the $0-0.5 \mathrm{~cm}$ layers) was observed (Spearman $\rho=0.857, \mathrm{n}=$ $8, p<0.05)$. This result is consistent with previous conclusions that the efficiency of organic matter recycling off the Rhône River is influenced by the input of labile OM in this area. In good agreement with the prominent role of bacteria in these muddy deposits, we found high contributions of bacterial fatty acids throughout all the cores (from 16 to $30 \%$ of total fatty, acids). Such high values of bacterial biomarkers are not unusual in depositional zones enriched in organic matter (e.g. 13 to $20 \%$ of total fatty acids in sediments from the Chilean coastal upwelling; Niggemann and Schubert, 2006). These high values could be explained by the presence of a specific benthic bacterial consortium involved in the recycling of the organic matter (Fagervold et al., 2014) in addition to the sedimentation of bacterioplankton on settling particles. OC-normalized yields of bacterial markers decreased in our sediment cores and were positively correlated with fatty acid concentrations (Spearman $\rho=0.98, \mathrm{n}=35, p<0.0001$ ). In this hypothesis, high bacterial remineralization was fuelled by the input of fresh reactive OM from the Rhône River.

\subsubsection{Role of oxygen in this environment}

Assuming a constant contribution of fatty acids to the sedimenting POC, OC-normalized concentrations reflect the degree of diagenetic alteration in the sediments (Fig. 4C). As expected, fatty acid degradation was more extensive than the general OC decline. For instance, $90 \%$ of the surface OC was still present in the deeper sediments $(7-10 \mathrm{~cm}$ layer) at station $\mathrm{C}$, whereas only $38 \%$ of the fatty acids remained (see online Supplementary Table S2). A sharp discontinuity separating the rapid disappearance of the fatty acids in the upper layer and the nearly constant yields below was observed for all the fatty acid subgroups with the exception of the LC-SAFAs 
(Fig. 6). In sediments from the coastal upwelling region off Chile, this discontinuity has been related to the extension of the mixed layer (Niggemann and Schubert, 2006). Off the Rhône River, the mixed layer (i.e. bioturbated sediments) encompasses the 10 first $\mathrm{cm}$ of sediments (i.e. $\sim 13 \mathrm{~cm}$ according to Pastor et al., 2011), but fatty acid degradation is restricted to a much narrower layer, suggesting that biological reworking is not the parameter controlling organic matter diagenesis. Instead, our results suggest that fatty acids are mostly degraded in the upper layer where oxic conditions are found.

The precise mechanisms involved in oxic degradation are still unclear. Hedges et al. (1999) stated that oxic degradation should be more appropriately viewed as a set of as yet unknown processes which characteristically prevail under sedimentary conditions where $\mathrm{O}_{2}$ is present, as opposed to a specific mechanism that directly involves molecular oxygen. Experimental studies have shown that the influence of oxygen on the metabolization of the different biochemical classes of compounds is variable. Under oxic conditions polysaccharides degrade faster than proteins, while the reverse situation is observed under anoxic conditions (Harvey et al., 1995). The different lipid classes also show different susceptibilities to diagenetic alteration and redox conditions, but as a general rule fatty acids are efficiently degraded in recent sediments and rates of decomposition are faster under oxic conditions (Sun and Wakeham, 1994; Canuel and Martens, 1996; Harvey and Macko, 1997; Sun et al., 1997; Sun et al., 2002; Ding and Sun, 2005). While for stations A, B and C, the extent of fatty acid degradation appears to be primarily controlled by the redox conditions, for the more distant stations ( $\mathrm{F}$ and $\mathrm{J}$ ) fatty acid removal is not observed over the whole oxic sediment layer (Fig. 6). This suggests that a fraction of the fatty acids that can account for $>50 \%$ at the marine reference station is not undergoing microbial remineralization (see Supplementary Table S2). 


\subsubsection{Structural and matrix effects}

Mayer (2004) defined the existence of protective mechanisms as a means to delay organic matter oxidation in the presence of oxidants that are thermodynamically capable of reaction. Organic matter degradability may be reduced by the formation of recalcitrant organic macromolecules to fulfill certain biological functions such as defense, structural strength and energy storage, or by humification reactions (Mayer, 2004). The importance of such structural and source effects on fatty acid degradation has been demonstrated experimentally. For instance, algal membrane fatty acids are more prone to degradation than intracellular triacylglycerols (Ding and Sun, 2005). Likewise, Dai et al. (2009) found that fatty acids from land and salt marsh plants were less reactive than fatty acids from diatoms, most probably because they are partially bound to waxes. In addition, the susceptibility of a molecule to diagenetic alteration is also related to its chemical structure (chain length and degree of unsaturation). As a result PUFAs are more prone to oxidation because of both their unsaturation and their abundance in membrane lipids of algae, while terrestrial derived LC-SAFAs are incorporated into complex matrixes such as lignin structures or cuticular waxes that protect them from microbial attack (see references above). Thus, the preservation of PUFAs in the deepest sediment layers was lower than that of LC-SAFAs at all stations (Fig. 6), except for the terrestrial PUFAs at the reference station where no trend was observed.

Another protective mechanism against enzymatic degradation is the adsorption and association of organic matter with clay minerals (Mayer et al., 2002). The adsorption of fatty acids to clay minerals is a rapid process significantly slowing down their degradation in the sediments and enhancing burial efficiency (Haddad et al., 1992; Lü et al., 2010). The Rhône 
fluvial system carries a diverse suite of clay particles dominated by illite and chlorite, and lower proportions of smectite, kaolinite, and montmorillonite (Touzani and Giresse, 2002) all with high adsorption potentials. These clay-size particles, which account for up to $26 \%$ of the mineral matrix at station $\mathrm{F}(0-0.5 \mathrm{~cm}$ layer $)$, may protect part of the labile organic matter against microbial degradation in sediments. In good agreement with this, density fractionations of sediments revealed that the contribution of organic matter bound with minerals increased along the offshore transect in the Rhône River deltaic system (from $46.4 \%$ at station A to $65.7 \%$ at 17 km offshore; Toussaint et al., 2013).

\subsubsection{Influence of depositional settings on fatty acid degradation rates}

As seen earlier, fatty acid inputs from riverine POC are diluted with marine material seaward of the river mouth and intensively degraded before reaching relatively uniform concentration profiles in deeper sediments. Their biogeochemical alteration continues after deposition and is affected by redox conditions, biological and physical reworking as well as structural effects. In agreement with results from other settings (Canuel and Martens, 1996; Niggemann and Schubert, 2006), the classes of fatty acids were degraded at different rates in the sediments. The PUFAs were the most reactive compounds, and the LC-SAFAs had the lowest degradability. The MC-SAFAs and bacterial fatty acids exhibited intermediate reactivity, as illustrated by the more pronounced loss of certain classes of fatty acids over OC in Fig. 6 and the percentages of fatty acids remaining in the deepest section in Table S2.

Results from cores at the five stations can only be interpreted if the depositional conditions at each station are treated within the framework of a reactive transport model. Thus degradation rate constants $(\mathrm{k})$ for selected components indicative of different sources, were 
calculated from the down-core concentration decreases (Table 3) in order to compare the biogeochemical fate of sedimentary fatty acids originating from different sources. One source of uncertainty in the estimated $\mathrm{k}$ values is the poor knowledge of transport parameters in this environment. Some sedimentation rates are reported for the continental shelf in Radakovitch et al. (1999), but values in the prodelta (stations A and B) are very uncertain, as such high sedimentation rates $(>10 \mathrm{~cm} / \mathrm{a}$ ) are difficult to measure with classical techniques (Charmasson et al., 1998). Bioturbation values were estimated by Pastor et al. (2011) by fitting a diagenesis model with distributions of several dissolved and particulate compounds and constitute indirect estimates. As a consequence, when comparing the $\mathrm{k}$ values between stations it should be recalled that these estimated values depend on the absolute value of transport parameters used in the calculation, which themselves are only known very approximately in our area. Intra-station comparison of $\mathrm{k}$ for different compounds, on the contrary, are more robust as transport parameters were treated as constants for each single station.

In the prodelta stations ( $\mathrm{A}$ and $\mathrm{B}$ ), it was impossible to get a good fit of the model to the observed data since fatty acid concentrations were scattered with no consistent trends. This is certainly related to the pulsed nature and unknown dynamics of a system which is associated with flood events (Cathalot et al., 2010) carrying material of different provenances and qualities. At the other stations located on the adjacent continental shelf, it is noteworthy that the shape of the modeled profile and the calculated degradation rate constant $(\mathrm{k})$ is largely determined by the initial concentration in the top layer $(0-0.5 \mathrm{~cm})$. In the steady-state model with active transport, the large decrease with depth is linked to the large degradation capacity of the pool of fatty acids considered in the topmost layer and hence to a large $\mathrm{k}$ value. This must be taken with caution as 
any non steady state behavior such as a recent depositional event of fresh organic carbon would provide the same fatty acid distribution, but a different interpretation of $\mathrm{k}$.

Degradation rate constants of individual fatty acids on the shelf area (from 10 to $131 \mathrm{a}^{-1}$; Table 3) were in the higher range of values reported for coastal and depositional settings (usually below 20-30, but may be as high as $426 \mathrm{a}^{-1 ;}$ Canuel and Martens, 1996; Sun and Wakeham, 1999; Arzayus and Canuel, 2004; Niggemann and Schubert, 2006). These values are consistent with the high degradation rate constants $\left(11\right.$ and $\left.33 \mathrm{a}^{-1}\right)$ calculated for the labile fraction of organic matter in the studied area (Pastor et al., 2011). Within a given core, the selected fatty acids showed different behaviors and no simple trends. Chain length usually affects the reactivity of the saturated fatty acids. For example, a progressive decrease of LC-SAFA reactivity with chain length was shown in sediments off Chile (Niggemann and Schubert, 2006). There was no clear chain length effect in our study apart from 26:0 which tended to accumulate with sediment depth at most stations (see Online Supplementary Fig. S1) confirming its relative stability during early diagenesis. At station F, however, the concentration of this compound decreased constantly with sediment depth. Although compositional changes in the inputs may vary over time, degradation during early diagenesis is the most likely explanation for the disappearance of 26:0 at this station. The reactivity of 26:0 remained lower than that of the other saturated fatty acids (by about a factor of $\sim 4$ fold), confirming that chain length or structure limits degradability. A large fraction of the phytoplanktonic unsaturated fatty acids were degraded within the first $10 \mathrm{~cm}$ of sediments (Table S2); estimates of the labile fraction with the model are in the range 87-96\% (Table 3). However, on the shelf, the degradation rate constants for the phytoplankton PUFAs were low in comparison to other fatty acids (20 and $60 \mathrm{a}^{-1}$ at stations $\mathrm{C}$ and $\mathrm{F}$, respectively) proving that they were less reactive than saturated fatty acids $\left(\mathrm{C}_{16}\right.$ or $\left.\mathrm{C}_{24}\right)$ and PUFAs derived 
from terrestrial plants ( 82 and $115 \mathrm{a}^{-1}$ at stations $\mathrm{C}$ and F respectively). Such a low degradability suggests that some unknown mechanisms have enabled the preservation of these chemically reactive biomolecules. Mechanisms such as physical entrapment and /or chemical incorporation into more refractory polymers could account for this observation. In good agreement with this assumption, $\delta^{13} \mathrm{C}$ and $\Delta^{14} \mathrm{C}$ measurements on suspended particles from the study area have shown that terrestrial inputs are diluted with recycled marine particles from the adjacent shelf (Cathalot et al., 2013). Labile biomarkers have been shown to have a low likelihood to survive lateral transport unless they are intimately associated to minerals (Mollenhauer and Eglinton, 2007). In contrast, in the prodelta, the nearly complete disappearance with sediment depth of the fatty acids deriving from freshwater phytoplankton is consistent with their association with a pool of fresh organic matter.

\subsection{Fate of sedimentary fatty acid in the Rhône deltaic system}

In coastal ecosystems, riverine organic inputs support the establishment of benthic communities (microbes and metazoan, adapted to exploit this nutritional resource), whose quantity and quality vary with season and river discharge. Off the Rhône River, surface and subsurface deposit-feeder species predominate, representing a link between continental POC and the marine food web (Harmelin-Vivien et al., 2009). Biogeochemical processes (burial and organic matter decomposition) are also directly affected by the benthic infauna that rework and irrigate the sediments (Grossi et al., 2003; Duport et al., 2007). However, high physical disturbance can decrease diversity (Hermand et al., 2008) and generally precludes macrofaunal biomass from dominating benthic communities in fluidized muds (Aller and Aller, 2004). In contrast, these muddy deposits are inhabited by highly active and diversified communities of 
bacteria and Archaea acting as a suboxic biogeochemical reactor which efficiently degrades both labile and refractory organic matter (Aller, 1998). Based on depositional regimes, redox conditions, and ecology, two general scenarios for the early diagenesis of fatty acids, and by extension the organic matter pool, were identified for the Rhône deltaic system (Fig. 7).

\subsubsection{The prodelta area scenarios (Fig. 7, scenarios $1 A$ and $1 B$ )}

In the prodelta area, sediment supply and quality of these inputs are a largely discontinuous phenomenon, subject to seasonal and climatic variability (Antonelli et al., 2008; Harmelin-Vivien et al., 2010; Dufois et al., 2014). While mixing due to physical or biological processes leads to uniform profiles, the presence of sub-surface maxima (stations A and B, Fig. 4B and 6) reflects the irregular inputs of terrestrial matter from the Rhône River. Fatty acid records over the first 10 centimeters of sediments indicate a persistent supply of material derived from higher plant detritus to the proximal area and low infaunal activity. Litter degradation on the continent leads to the incorporation of long chain fatty acids to humus and soils (Wiesenberg and Schwark, 2006), which may be exported to the marine system as a result of soil erosion or floods (Hatten et al., 2012). Because much of the particulate inputs from the Rhône are delivered during flood events ( $\sim 80 \%$; Antonelli et al., 2008), soil-derived organic carbon certainly represents a non-negligible source of fatty acids for the area.

Our sediment cores collected in the vicinity of the Rhône mouth recorded at least two flood events (scenario 1A, a large flood event). At station A, a thick layer located between 1 and $7 \mathrm{~cm}$ depth was characterized by high $\mathrm{OC}(>2 \%)$ and total lipid contents $(>1.3 \mathrm{mg} / \mathrm{g} \mathrm{DW})$, higher contributions of terrestrial biomarkers and the presence of plant macrodetritus (microscopic observations; R. Buscail unpublished data, 2012). Considering the hydrologic 
regime of the Rhône in the months previous, these deposits may be attributed to the Cevenoletype floods of November-December, 2006. These extreme events transported autumnal phytodetritic material and substantial amounts of sediments (15\% of the annual suspended particulate matter; Eyrolle et al., 2012) to the Rhône prodelta leading to the deposition of 3 to 11 $\mathrm{cm}$ of sediments in front of the river mouth (as evidenced by radiotracer activity on sediment cores collected in the same area 2 weeks before our sampling; Marion et al., 2010). As the distance from the mouth increased, the traces of the autumnal floods in the sediments decreased $(\sim 2 \mathrm{~cm}$ at station $\mathrm{B})$. Consistent with the retention of autumnal plant debris in the prodelta area (Tesi et al., 2007), a positive correlation was found in the prodelta cores between the concentration in LC-SAFAs and the coarse-sized particles $(n=14$, Spearman $\rho=0.616, p=$ 0.001). The following winter was characterized by low river runoff and little deposition in front of the river mouth apart from a small flood of the northern tributaries in March (Marion et al., 2010). This event accounted for $15 \%$ of the annual solid inputs in 2007 (Eyrolle et al., 2012) and the suspended particles were depleted in organic carbon(P. Kerhervé, pers. com.) typical for high discharge regime events of the Rhône River. It also explains the lower organic carbon and total lipid contents observed over the upper sequence $(\sim 1 \mathrm{~cm})$ of the core collected at station A. In agreement with their flood origin, these deposits were characterized by a high contribution of soil-derived organic carbon (> 70\%, Kim et al., 2010). Polyunsaturated fatty acids of phytoplankton origin were also found in the top layer $(0-0.5 \mathrm{~cm})$, confirming that freshwater phytoplankton may represent a non-negligible source of labile POC in spring (Harmelin-Vivien et al., 2010). Compositional changes linked with river flow or season are likely to affect organic matter recycling by the microbial benthic compartment and certainly account for some of the benthic oxygen demand variability off the Rhône River (Cathalot et al., 2010). The net loss of 
fatty acid biomarkers relative to organic carbon confirms that fresh terrestrial inputs are actively recycled in the prodelta benthic system (scenario 1B, normal river flow and runoff). However, organic matter flux in the prodelta is the dominant process affecting the fate of terrestrial OM and the area is essentially a burial center (burial efficiency of 80\%; Pastor et al., 2011) where episodic inputs, hydrodynamic sorting, limited faunal activity, poor sediment oxygenation and the prevalence of anaerobic degradation pathways allow for the preservation of fatty acids and, more generally speaking, labile organic matter deriving from fresh continental sources.

\subsubsection{The shelf area scenario (Fig. 7, scenario 2)}

In the shelf area, the influence of the Rhône River is directed to the south-west and sedimentation rates decrease with distance from the river mouth. Degradation rate constants in the proximal shelf area (station C) were in the higher range of those reported for other coastal shelves (Camacho-Ibar et al., 2003; Niggemann and Schubert, 2006). These findings suggest that although the inputs of POC from the Rhône River are more limited than in the prodelta area, they are sufficiently abundant and labile to enhance microbial degradation and support rich benthic communities whose ingestion and mixing activities favor organic matter decomposition. The high densities of Sternaspis scutata found at station C in April 2007 (Labrune et al., 2012) can certainly be explained by the more stable conditions and the enrichment of the surface sediments in readily bioavailable organic matter, a relationship previously generalized by Hermand et al. (2008) in the study area. Further offshore, as lower net accumulation rates are encountered, terrestrial OM becomes more degraded and is diluted with pre-aged autochthonous matter (Table 1), accounting for the low reactivity of the phytoplankton PUFA (Table 3). This is in agreement with the isotopic signature which shows isotopically heavier and older material accumulated with 
the distance to the river (Cathalot et al., 2013).

Degradation constant $\mathrm{k}$ values were high further out on the shelf (station F) in comparison to the estimates for the core collected at the eastern marine reference $(\mathrm{J})$. These two stations are located at a similar depth and share some features such as similar accumulation rates, organic carbon content, contribution of terrestrial OM, and infaunal reworking activity (Table 1). Thus, differences in the nature or quality of the sedimented POM may explain the apparent slower degradation of fatty acids at the reference station as previously reported in two contrasted depositional regions off Chile (Niggemann and Schubert, 2006). The biochemical composition of the surficial deposits confirms the lower lability of the organic inputs that settle at station J (e.g. lower PUFA content and biovailability of the amino acid fraction, higher degradation of the pigment pool; see discussion in Bourgeois et al., 2011). In contrast, station $\mathrm{F}$ benefits from the enhancement of pelagic primary production by the nutrient-rich river plume (Pujo-Pay et al., 2006). The inputs of fresh marine material, even in small amounts at some periods of the year could promote the degradation of labile and more refractory materials by a process known as the “priming effect" (Bianchi, 2011). Accordingly, k values for total fatty acids were 20 times higher than at the eastern marine reference, where intrusions of the dilution plume are rare and limit primary productivity. It should be stressed that a suite of isotopic and compositional tracers indicate little terrestrial or marine labile organic matter accumulation in shelf sediments (Bourgeois et al., 2011; Cathalot et al., 2013). In summary, inputs of relatively labile biogenic organic matter from the Rhône River watershed and sedimentation of some autochthonous material account for the faster degradation of sedimentary fatty acids on the more oxygenated and less disturbed adjacent shelf area exposed to the Rhône influence (scenario 2, Fig. 7). 


\section{Conclusions}

A wide range of large and small rivers contribute significantly to the export of terrestrial organic carbon to the Mediterranean Sea. However, because of the distinct seasonality of the inputs and torrential behavior of these rivers, the geochemical fate of the terrestrial POC delivered to the continental margin is still poorly constrained. To better resolve the fate of landderived organic matter in the coastal environment, we have investigated the main factors governing the early diagenesis of sedimentary fatty acids in a typical Mediterranean shallow water deltaic-shelf system. Hierarchical cluster analysis based on fatty acid biomarkers clearly delineates the two principal sources of particulate organic matter in the area, namely the terrestrial plant detritus and decaying phytoplankton inputs.

Our results indicate that earlier concepts about the reactivity of organic matter and broadly defined divisions into refractory terrestrial and labile allochthonous organic sources overlooked important possibilities for organic matter recycling in these complex and dynamic nearshore systems. Far from the general eutrophication issue associated with large rivers (Cloern, 2001), the Rhône River delivers a relatively labile and biodegradable source of particulate organic matter which fertilizes the otherwise oligotrophic seafloor environment and participates in the benthic food web. In the microtidal regime of the Mediterranean Sea, fine grained sediment enriched in organic carbon from recent soils and plant fragments accumulates close to the shoreline at shallow depths $(25-30 \mathrm{~m})$ where episodic inputs and low oxygenation favor organic matter preservation. A little further from the shore $(\sim 8 \mathrm{~km})$, as disturbance and accumulation rates decrease, a high potential for the degradation of biogenic compounds is observed. The decay of this labile fraction of the particulate organic matter was mainly constrained by the provenance and nature of the inputs, their chemical alteration prior their 
incorporation to the sediments, and the physico-chemical conditions. Fatty acid degradation occurred mostly in the oxic zone and was extremely reduced below the redox potential discontinuity. Physical means of preservation account for the persistence of fatty acids in deeper sediment layers. Finally, on an inter annual time scale, river runoff variability (e.g. floods) and meteorological conditions (e.g. winter storms) which affect the deposition, remobilization (erosion) and export of terrigenous POC on the Rhône delta-shelf system are likely to be key factors controlling the fate of biogenic inputs in these high energy environments.

\section{Acknowledgments}

We are grateful to Dr M. Yunker, Dr J. Volkman, and two anonymous reviewers for their constructive comments. We thank the captain and crew of the R.V. Tethys II, as well as numerous colleagues, for their hard work at sea and in port. We express our sincere gratitude to K. Escoubeyrou for sediment conditioning on board, M. Desmalades for his help at sea and in the laboratory with grain size analyses and B. Bombled who was in charge of the multicorer. We are also grateful to G. Jeanty who performed the elemental analyses and P. Kerhervé for providing the river sample and for numerous discussions on the characteristics of Rhodanian suspended POC inputs. We thank J.-J. Naudin, chief scientist of the CHACCRA-plume cruise (April 2008), for providing us with seawater samples, B. Hebert who assisted us with QGIS for the elaboration of the location map and V. Domien for her help to design the graphical abstract. This research was funded by the French National Research Agency, program "Vulnérabilités:

Milieux et Climat" under the grant CHACCRA (contract number ANR-VULN-06-001-01), the French INSU-EC2CO program RiOMar.fr, the Mermex/MISTRALS program, CNRS and 
Université Pierre et Marie Curie. S.B. was supported by a PhD scholarship from the French ministry of research and education. JC-G was supported by a training grant provided by UPMC.

Associate Editor - Mark Yunker

\section{References}

Aitchison, J., 2003. The Statistical Analysis of Compositional Data. The Blackburn Press, Caldwell, N.J.

Ali, M.M., Mudge, S.M., 2006. Cluster analysis in lipid biomarker studies: a case of the Clyde Sea. Sains Malaysiana 35, 41-47.

Aller, J.Y., Aller, R.C., 2004. Physical disturbance creates bacterial dominance of benthic biological communities in tropical deltaic environments of the Gulf of Papua. Continental Shelf Research 24, 2395-2416.

Aller, R.C., 1998. Mobile deltaic and continental shelf muds as suboxic, fluidized bed reactors. Marine Chemistry 61, 143-155.

Aloisi, J.C., Auffret, G.A., Auffret, J.P., Barusseau, J.P., Hommeril, P., Larsonneur, C., Monaco, A., 1977. Essai de modélisation de la sédimentation actuelle sur les plateaux continentaux français. Bulletin de la Société Géologique de France 7, 183-195.

Aloisi, J.C., Millot, C., Monaco, A., Pauc, H., 1979. Dynamique des suspensions et mécanismes sédimentogénétiques sur le plateau continental du Golfe du Lion. Comptes Rendus de l'Académie des Sciences Paris Serie D 289, 879-882. 
Antonelli, C., Eyrolle, F., Rolland, B., Provansal, M., Sabatier, F., 2008. Suspended sediment and ${ }^{137}$ Cs fluxes during the exceptional December 2003 flood in the Rhône River, southeast France. Geomorphology 95, 350-360.

AQUASTAT, 2014. Global River Sediment Yields Database. FAO’s Information System on Water and Agriculture. http://www.fao.org/nr/Water/aquastat/sediment/index.asp, last accessed 12/27/2014.

Arzayus, K.M., Canuel, E.A., 2004. Organic matter degradation in sediments of the York River estuary: Effects of biological vs. physical mixing. Geochimica et Cosmochimica Acta 69, 455-464.

Barnes, H., Blackstock, J., 1973. Estimation of lipids in marine animals and tissue: detailed investigations of the sulfovanilin method for total lipids. Journal of Experimental Marine Biology and Ecology 12, 103-118.

Barros, L., Carvalho, A.M., Ferreira, I.C.F.R., 2010. Leaves, flowers, immature fruits and leafy flowered stems of Malva sylvestris: A comparative study of the nutraceutical potential and composition. Food and Chemical Toxicology 48, 1466-1472.

Berner, R.A., 1980. Early Diagenesis: A Theoretical Approach. Princeton University Press.

Berné, S., Carré, D., Loubrieu, B., Mazé, J.P., Normand, A., 2001. Carte morpho-bathymétrique du Golfe du Lion. 4 feuilles, échelle 1/100 000e. IFREMER - Région LanguedocRoussillon.

Bianchi, T.S., 2011. The role of terrestrially derived organic carbon in the coastal ocean: A changing paradigm and the priming effect. Proceedings of the National Academy of Sciences of the United States of America 108, 19473-19481. 
Bourgeois, S., Pruski, A.M., Sun, M.-Y., Buscail, R., Lantoine, F., Kerhervé, P., Vétion, G., Rivière, B., Charles, F., 2011. Distribution and lability of land-derived organic matter in the surface sediments of the Rhône prodelta and the adjacent shelf (Mediterranean Sea, France): a multi proxy study. Biogeosciences 8, 3107-3125.

Budge, S.M., Parrish, C.C., McKenzie, C.H., 2001. Fatty acid composition of phytoplankton, settling particulate matter and sediments at a sheltered bivalve aquaculture site. Marine Chemistry 76, 285-303.

Burdige, D.J., 2007. Preservation of organic matter in marine sediments: Controls, mechanisms, and an imbalance in sediment organic carbon budgets? Chemical Reviews 107, 467-485.

Camacho-Ibar, V.F., Aveytua-Alcazar, L., Carriquiry, J.D., 2003. Fatty acid reactivities in sediment cores from the northern Gulf of California. Organic Geochemistry 34, 425-439.

Canuel, E.A., Cloern, J.E., Ringelberg, D.B., Guckert, J.B., Rau, G.H., 1995. Molecular and isotopic tracers used to examine sources of organic matter and its incorporation into the food webs of San Francisco Bay. Limnology and Oceanography 40, 67-81.

Canuel, E.A., Martens, C.S., 1996. Reactivity of recently deposited organic matter: Degradation of lipid compounds near the sediment-water interface. Geochimica et Cosmochimica Acta 60, 1793-1806.

Cathalot, C., Rabouille, C., Pastor, L., Deflandre, B., Viollier, E., Buscail, R., Grémare, A., Treignier, C., Pruski, A., 2010. Temporal variability of carbon recycling in coastal sediments influenced by rivers: assessing the impact of flood inputs in the Rhône River prodelta. Biogeosciences 7, 1187-1205.

Cathalot, C., Rabouille, C., Tisnerat-Laborde, N., Toussaint, F., Kerherve, P., Buscail, R., Loftis, K., Sun, M.-Y., Tronczynski, J., Azoury, S., Lansard, B., Treignier, C., Pastor, L., Tesi, 
T., 2013. The fate of river organic carbon in coastal areas: A study in the Rhone River delta using multiple isotopic $\left(\delta \mathrm{C}^{13}, \Delta \mathrm{C}^{14}\right)$ and organic tracers. Geochimica et Cosmochimica Acta 118, 33-55.

Cauwet, G., Gadel, F., de Souza Sierra, M.M., Donard, O., Ewald, M., 1990. Contribution of the Rhône River to organic carbon inputs to the northwestern Mediterranean Sea. Continental Shelf Research 10, 1025-1037.

Charmasson, S., Radakovitch, O., Arnaud, M., Bouisset, P., Pruchon, A.S., 1998. Long-core profiles of ${ }^{137} \mathrm{Cs},{ }^{134} \mathrm{Cs},{ }^{60} \mathrm{Co}$ and ${ }^{210} \mathrm{~Pb}$ in sediment near the Rhone river (northwestern Mediterranean Sea). Estuaries and Coasts 21, 367-378.

Cloern, J.E., 2001. Our evolving conceptual model of the coastal eutrophication problem. Marine Ecology Progress Series 210, 223-253.

Cook, P.L.M., Revill, A.T., Clementson, L.A., Volkman, J.K., 2004. Carbon and nitrogen cycling on intertidal mudflats of a temperate Australian estuary. III. Sources of organic matter. Marine Ecology Progress Series 280, 55-72.

Dai, J., Sun, M.-Y., Culp, R.A., Noakes, J.E., 2009. A laboratory study on biochemical degradation and microbial utilization of organic matter comprising a marine diatom, land grass, and salt marsh plant in estuarine ecosystems. Aquatic Ecology 43, 825-841.

Dauwe, B., Middelburg, J., Herman, P., 2001. Effect of oxygen on the degradability of organic matter in subtidal and intertidal sediments of the North Sea area. Marine Ecology Progress Series 215, 13-22.

Ding, H., Sun, M.-Y., 2005. Biochemical degradation of algal fatty acids in oxic and anoxic sediment-seawater interface systems: effects of structural association and relative roles of aerobic and anaerobic bacteria. Marine Chemistry 93, 1-19. 
Dufois, F., Verney, R., Le Hir, P., Dumas, F., Charmasson, S., 2014. Impact of winter storms on sediment erosion in the Rhone River prodelta and fate of sediment in the Gulf of Lions (North Western Mediterranean Sea). Continental Shelf Research 72, 57-72.

Dunstan, G.A., Volkman, J.K., Barrett, S.M., Leroi, J.M., Jeffrey, S.W., 1994. Essential polyunsaturated fatty acids from 14 species of diatom (Bacillariophyceae). Phytochemistry 35, 155-161.

Duport, E., Gilbert, F., Poggiale, J.-C., Dedieu, K., Rabouille, C., Stora, G., 2007. Benthic macrofauna and sediment reworking quantification in contrasted environments in the Thau Lagoon. Estuarine and Coastal Shelf Science 72, 522-533.

Eadie, B.J., McKee, B.A., Lansing, M.B., Robbins, J.A., Metz, S., Trefry, J.H., 1994. Records of nutrient-enhanced coastal ocean productivity in sediments from the Louisiana Continental Shelf. Estuaries 17, 754.

Eyrolle, F., Radakovitch, O., Raimbault, P., Charmasson, S., Antonelli, C., Ferrand, E., Aubert, D., Raccasi, G., Jacquet, S., Gurriaran, R., 2012. Consequences of hydrological events on the delivery of suspended sediment and associated radionuclides from the Rhône River to the Mediterranean Sea. Journal of Soils and Sediments 12, 1479-1495.

Fagervold, S.K., Bourgeois, S., Pruski, A.M., Charles, F., Kerhervé, P., Vétion, G., Galand, P.E., 2014. River organic matter shapes microbial communities in the sediment of the Rhône prodelta. The ISME Journal 8, 2237-2238.

Ferreira, L.M.M., Celaya, R., Santos, A.S., Falco, V., Guedes, C., Rodrigues, M.A.M., Osoro, K., 2011. The utilization of long-chain fatty acids as markers for diet composition estimates in ruminants: effects of animal species, diet composition and marker combination. Grass Forage Science 66, 183-195. 
Grossi, V., Caradec, S., Gilbert, F., 2003. Burial and reactivity of sedimentary microalgal lipids in bioturbated Mediterranean coastal sediments. Marine Chemistry 81, 57-69.

Gunstone, F., Hartwood, J., Dijkstra, A., 2007. The Lipid Handbook with CD-ROM, Third Edition, CRC Press.

Haddad, R.I., Martens, C.S., Farrington, J.W., 1992. Quantifying early diagenesis of fatty acids in a rapidly accumulating coastal marine sediment. Organic Geochemistry 19, 205-216.

Harmelin-Vivien, M., Dierking, J., Bănaru, D., Fontaine, M.F., Arlhac, D., 2010. Seasonal variation in stable $\mathrm{C}$ and $\mathrm{N}$ isotope ratios of the Rhone River inputs to the Mediterranean Sea (2004-2005). Biogeochemistry 100, 139-150.

Harmelin-Vivien, M.L., Banaru, D., Dierking, J., Hermand, R., Letourneur, Y., Salen-Picard, C., 2009. Linking benthic biodiversity to the functioning of coastal ecosystems subjected to river runoff (NW Mediterranean). Animal Biodiversity and Conservation 32, 135-145.

Harvey, H.R., Macko, S.A., 1997. Catalysts or contributors? Tracking bacterial mediation of early diagenesis in the marine water column. Organic Geochemistry 26, 531-544.

Harvey, R.H., Tuttle, J.H., Bell, J.T., 1995. Kinetics of phytoplankton decay during simulated sedimentation: changes in biochemical composition and microbial activity under oxic and anoxic conditions. Geochimica et Cosmochimica Acta 59, 3367-3377.

Hatten, J., Goñi, M., Wheatcroft, R., 2012. Chemical characteristics of particulate organic matter from a small, mountainous river system in the Oregon Coast Range, USA. Biogeochemistry 107, 43-66.

Hedges, J.I., Hu, F.S., Devol, A.H., Hartnett, H.E., Tsamakis, E., Keil, R.G., 1999. Sedimentary organic matter preservation; a test for selective degradation under oxic conditions. American Journal of Science 299, 529-555. 
Hedges, J.I., Keil, R.G., Benner, R., 1997. What happens to terrestrial organic matter in the ocean? Organic Geochemistry 27, 195-212.

Hermand, R., Salen-Picard, C., Alliot, E., Degiovanni, C., 2008. Macrofaunal density, biomass and composition of estuarine sediments and their relationship to the river plume of the Rhône River (NW Mediterranean). Estuarine and Coastal Shelf Science 79, 367-376.

Kim, J., Zarzycka, B., Buscail, R., Peterse, F., Bonnin, J., Ludwig, W., Schouten, S., Sinninghe Damsté, J.S., 2010. Contribution of river-borne soil organic carbon to the Gulf of Lions (NW Mediterranean). Limnology and Oceanography 55, 507-518.

Labrune, C., Romero-Ramirez, A., Amouroux, J.M., Duchêne, J.C., Desmalades, M., Escoubeyrou, K., Buscail, R., Grémare, A., 2012. Comparison of ecological quality indices based on benthic macrofauna and sediment profile images: A case study along an organic enrichment gradient off the Rhône River. Ecological Indicators 12, 133-142.

Lü, D., Song, Q., Wang, X., 2010. Decomposition of algal lipids in clay-enriched marine sediment under oxic and anoxic conditions. Chinese Journal of Oceanology and Limnology 28, 131-143.

Mansour, M.P., Volkman, J.K., Jackson, A.E., Blackburn, S.I., 1999. The fatty acid and sterol composition of five marine dinoflagellates. Journal of Phycology 35, 710-720.

Marion, C., Dufois, F., Arnaud, M., Vella, C., 2010. In situ record of sedimentary processes near the Rhône River mouth during winter events (Gulf of Lions, Mediterranean Sea). Continental and Shelf Research 30, 1095-1107.

Martín-Fernández, J.A., Barceló-Vidal, C., Pawlowsky-Glahn, V., 1998. A Critical Approach to Non-Parametric Classification of Compositional Data. In: Rizzi, P.A., Vichi, P.M., Bock, 
P.D.H.-H. (Eds.), Advances in Data Science and Classification, Studies in Classification, Data Analysis, and Knowledge Organization. Springer, Berlin Heidelberg, pp. 49-56.

Mayer, L., Benninger, L., Bock, M., DeMaster, D., Roberts, Q., Martens, C., 2002. Mineral associations and nutritional quality of organic matter in shelf and upper slope sediments off Cape Hatteras, USA: a case of unusually high loadings. Deep Sea Research Part II Topical Studies in Oceanography 49, 4587-4597.

Mayer, L.M., 2004. The inertness of being organic. Marine Chemistry 92, 135-140.

Mayer, L.M., Schick, L.L., Allison, M.A., 2008. Input of nutritionally rich organic matter from the Mississippi River to the Louisiana coastal zone. Estuaries and Coasts 31, 1052-1062.

McKee, B.A., Aller, R.C., Allison, M.A., Bianchi, T.S., Kineke, G.C., 2004. Transport and transformation of dissolved and particulate materials on continental margins influenced by major rivers: benthic boundary layer and seabed processes. Continental and Shelf Research 24, 899-926.

Meyers, P.A., 1997. Organic geochemical proxies of paleoceanographic, paleolimnologic, and paleoclimatic processes. Organic Geochemistry 27, 213-250.

Meziane, T., Bodineau, L., Retiere, C., Thoumelin, G., 1997. The use of lipid markers to define sources of organic matter in sediment and food web of the intertidal salt-marsh-flat ecosystem of Mont-Saint-Michel Bay, France. Journal of Sea Research 38, 47-58.

Mollenhauer, G., Eglinton, T.I., 2007. Diagenetic and sedimentological controls on the composition of organic matter preserved in California Borderland Basin sediments. Limnology and Oceanography 52, 558-576. 
Mrozik, A., Nowak, A., Piotrowska-Seget, Z., 2014. Microbial diversity in waters, sediments and microbial mats evaluated using fatty acid-based methods. International Journal of Environmental Science and Technology 11, 1487-1496.

Nahon, S., Charles, F., Lantoine, F., Vétion, G., Escoubeyrou, K., Desmalades, M., Pruski, A.M., 2010. Ultraviolet radiation negatively affects growth and food quality of the pelagic diatom Skeletonema costatum. Journal of Experimental Marine Biology and Ecology 383, $164-170$.

Naudin, J.J., Cauwet, G., Chrétiennot-Dinet, M.J., Deniaux, B., Devenon, J.L., Pauc, H., 1997. River discharge and wind influence upon particulate transfer at the land-ocean interaction: case study of the Rhone River plume. Estuarine and Coastal Shelf Science $45,303-316$.

Niggemann, J., Schubert, C.J., 2006. Fatty acid biogeochemistry of sediments from the Chilean coastal upwelling region: Sources and diagenetic changes. Organic Geochemistry 37, $626-647$.

Pastor, L., Cathalot, C., Deflandre, B., Viollier, E., Soetaert, K., Meysman, F.J.R., Ulses, C., Metzger, E., Rabouille, C., 2011. Modeling biogeochemical processes in sediments from the Rhône River prodelta area (NW Mediterranean Sea). Biogeosciences 8, 1351-1366.

Pujo-Pay, M., Conan, P., Joux, F., Oriol, L., Naudin, J.J., Cauwet, G., 2006. Impact of phytoplankton and bacterial production on nutrient and DOM uptake in the Rhone river plume (NW Mediterranean). Marine Ecology Progress Series 315, 43-54.

Radakovitch, O., Charmasson, S., Arnaud, M., Bouisset, P., 1999. ${ }^{210} \mathrm{~Pb}$ and caesium accumulation in the Rhone delta sediments. Estuarine and Coastal Shelf Science 48, 7792. 
Shi, W., Sun, M.-Y., Molina, M., Hodson, R.E., 2001. Variability in the distribution of lipid biomarkers and their molecular isotopic composition in Altamaha estuarine sediments: implications for the relative contribution of organic matter from various sources. Organic Geochemistry 32, 453-467.

Stanley, D.J., 1997. Mediterranean deltas : subsidence as a major control of relative sea-level rise. Bulletin de l'Institut Océanographic special issue 18, 35-62.

Sun, M.-Y., Cai, W.-J., Joye, S.B., Ding, H., Dai, J., Hollibaugh, J.T., 2002. Degradation of algal lipids in microcosm sediments with different mixing regimes. Organic Geochemistry 33, 445-459.

Sun, M.-Y., Wakeham, S.G., 1994. Molecular evidence for degradation and preservation of organic matter in the anoxic Black Sea Basin. Geochimica Cosmochimica Acta 58, 33953406.

Sun, M.-Y., Wakeham, S.G., 1999. Diagenesis of planktonic fatty acids and sterols in Long Island Sound sediments: Influences of a phytoplankton bloom and bottom water oxygen content. Journal of Marine Research 57, 357-385.

Sun, M.-Y., Wakeham, S.G., Lee, C., 1997. Rates and mechanisms of fatty acid degradation in oxic and anoxic coastal marine sediments of Long Island Sound, New York, USA. Geochimica et Cosmochimica Acta 61, 341-355.

Tesi, T., Miserocchi, S., Goñi, M.., Langone, L., 2007. Source, transport and fate of terrestrial organic carbon on the western Mediterranean Sea, Gulf of Lions, France. Marine Chemistry 105, 101-117. 
Toussaint, F., Tisnerat-Laborde, N., Cathalot, C., Buscail, R., Kerhervé, P., Rabouille, C., 2013. Depositional processes of organic matter in the Rhone River delta (Gulf of Lion, France) traced by density fractionation coupled with $\Delta^{14} \mathrm{C}$ and $\delta^{13} \mathrm{C}$. Radiocarbon $55,920-931$.

Touzani, A., Giresse, P., 2002. The Rhone River prodelta: short-term $\left(10^{0}-10^{3}\right.$ year $)$ sedimentation patterns and human impact. Journal of Coastal Research 18, 102-117.

Vainshtein, M., Hippe, H., Kroppenstedt, R.M., 1992. Cellular fatty acid composition of Desulfovibrio species and its use in classification of sulfate-reducing bacteria. Systematic and Applied Microbiology 15, 554-566.

Venturini, N., Salhi, M., Bessonart, M., Pires-Vanin, A.M.S., 2012. Fatty acid biomarkers of organic matter sources and early diagenetic signatures in sediments from a coastal upwelling area (south-eastern Brazil). Chemistry and Ecology 28, 221-238.

Viano, J., Masotti, V., Gaydou, E.M., Bourreil, P.J.L., Ghiglione, C., Giraud, M., 1995. Compositional characteristics of 10 wild plant legumes from Mediterranean French pastures. Journal of Agricultural and Food Chemistry 43, 680-683.

Viso, A.-C., Marty, J.-C., 1993. Fatty acids from 28 marine microalgae. Phytochemistry 34, $1521-1533$.

Wannigama, G.P., Volkman, J.K., Gillan, F.T., Nichols, P.D., Johns, R.B., 1981. A comparison of lipid components of the fresh and dead leaves and pneumatophores of the mangrove Avicennia marina. Phytochemistry 20, 659-666.

Ward, J.H., 1963. Hierarchical grouping to optimize an objective function. Journal of the American Statistical Association 58, 236-244. 
Waterson, E.J., Canuel, E.A., 2008. Sources of sedimentary organic matter in the Mississippi River and adjacent Gulf of Mexico as revealed by lipid biomarker and $\delta^{13} \mathrm{C}_{\mathrm{TOC}}$ analyses. Organic Geochemistry 39, 422-439.

Wiesenberg, G.L.B., Schwark, L., 2006. Carboxylic acid distribution patterns of temperate $\mathrm{C}_{3}$ and $\mathrm{C}_{4}$ crops. Organic Geochemistry 37, 1973-1982. 


\section{Figure captions}

Fig. 1. Map of the Rhône River delta and adjacent shelf area, including the locations of the five sampling stations (RioMAr 1 field campaign, April 2007; overview from Berné et al., 2001).

Fig. 2. Vertical distributions of grain size fractions in cores from the five stations (A, B, C, F and J) sampled. Note that sites A and B closer to the river mouth have coarser material than the 3 more offshore sites.

Fig. 3. Sedimentary sequences and oxidation-reduction potential depth profiles in sediments cores from stations A, B, C, F and J. Four sedimentary facies were defined based on their color: ochre (I), grey-ochre (II), dark grey (III), and black (IV) muds. Eh values (white diamonds) are expressed in $\mathrm{mV}$. The thickness of the ochre and grey-ochre mud layers, colors indicative of oxidizing conditions, gradually increased with distance offshore and eventually made up the entire sedimentary sequence in cores from the distal and reference stations ( $\mathrm{F}$ and $\mathrm{J}$, respectively). In contrast, reduced dark grey and/or back muds characterized nearshore deposits (<8.6 km offshore; stations A, B and C).

Fig. 4. Down-core changes in organic carbon (OC), total lipids and fatty acids concentrations in the upper $10 \mathrm{~cm}$ at stations A, B, C, F and J. For panel A, values are the mean \pm standard deviation $(n=3)$.

Fig. 5. Dendrogram of hierarchical clustering with Ward's method showing the degree of similarity of the distribution of fatty acids identified in the sediments. The horizontal scale denotes the increase in within-cluster variance. Blocks of compounds, nominally from the same source, have been highlighted. This method groups the fatty acids into four clusters.

Fig. 6. Down-core distribution of fatty acid subgroups at stations A, B, C, F and J. Yields (mg/g OC) are plotted at the mid depth of the layer. The dashed horizontal lines indicate the oxygen 
penetration depth and the shaded areas correspond to the oxic sediments. Note that with OCnormalized concentrations a decrease in concentration with depth illustrates the preferential degradation of this compound relative to OC, but if the compound is degraded at the same speed as OC no variation in concentration is observed. MC-SAFAs: mid chain saturated fatty acids, LC-SAFA: long chain saturated fatty acids, MUFAs: monounsaturated fatty acids, Phyto PUFAs: polyunsaturated fatty acids of phytoplanktonic origin, Terr PUFAs: polyunsaturated fatty acids from terrestrial plants, BACT: bacterial fatty acids.

Fig. 7. Conceptual schemes describing the main processes and variables affecting the fate of fatty acids in the Rhône River deltaic system. Degradation (grazing, microbial) occurs during transport in the water column, in sediments, and after resuspension. Under specific meteorological and hydrodynamic conditions of rapid deposition and burial, such as in a flood, scenario $1 \mathrm{~A}$ is possible allowing the preservation of terrestrial fatty acids in deeper sediment layers in the prodelta area. Alternatively, during conditions of normal river regime (scenario 1B), degradation is more efficient due to increase time of exposure to $\mathrm{O}_{2}$ in the sediment and resuspension events through hydrodynamic action (waves, currents, storms). Sediments may also be remobilized and exported further offshore. On the adjacent shelf (scenario 2), terrestrial and marine inputs mix prior to deposition. The organic matter signature is the result of mixing different sources, with differing reactivities under a range of possible conditions that depend on ecological and environmental parameters. Redox conditions and pulse of labile organic matter stimulate fatty acid degradation. 


\section{Supplementary data}

Table S1. Fatty acid composition of sediments from the Rhône prodelta and adjacent shelf in April 2007. Data are expressed in percentages of total fatty acid concentrations. MC-SAFAs: Mid-chain saturated fatty acids $\left(<\mathrm{C}_{20}\right)$, LC-SAFAs: Long-chain saturated fatty acids $\left(\geq \mathrm{C}_{20}\right)$,

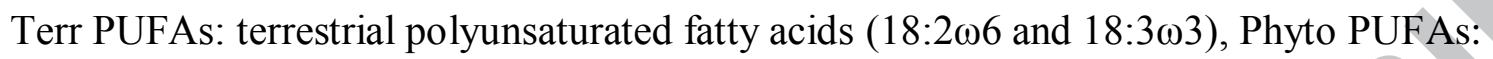
phytoplankton polyunsaturated fatty acids (all except Terr PUFAs), MUFAs: monounsaturated fatty acids, BACT: straight and branched odd-numbered fatty acids.

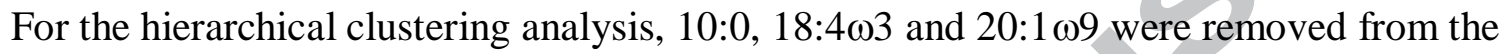
dataset. Percentages were recalculated on the 25 remaining fatty acids and a centered log-ratio transformation was applied.

Table S2. Proportions of biogenic compounds in the deepest section $(7-10 \mathrm{~cm})$ of sediment relative to their concentration in the $0-0.5 \mathrm{~cm}$ layer in the same core (values are expressed as percentages). OC: organic carbon, $\Sigma$ FAs: sum of all fatty acids, MC-SAFAs: mid chain saturated fatty acids, LC-SAFA: long chain saturated fatty acids, MUFAs: monounsaturated fatty acids, Phyto PUFAs: polyunsaturated fatty acids of phytoplanktonic origin, Terr PUFAs: polyunsaturated fatty acids from terrestrial plants, BACT: bacterial fatty acids.

Fig. S1. Vertical profiles of the concentrations of selected fatty acids in the cores collected at stations C, F and J showing observed and modeled concentrations ( $\mu \mathrm{g} / \mathrm{g})$. The dashed horizontal line indicates the oxygen penetration depth and the yellow areas correspond to the oxic sediments. Note that the general good fit of the model confirms the existence of two pools of 
fatty acids; a labile pool rapidly degraded in the oxidized upper sediments and a more refractory pool whose concentrations remain constant within the first $10 \mathrm{~cm}$ of sediment.

Appendix B: supplementary geospatial data 


\section{Tables}

Table 1. Sampling sites with position, water depth, distance from the Rhône River mouth (km), and environmental parameters relevant to early diagenesis: sediment accumulation rate $(\omega)$, proportion of degradation pigments in the surface sediments, $\delta^{13} \mathrm{C}$ of OC in the surface sediments, depth of the redox potential discontinuity (RPD), oxygen penetration depth (OPD), in situ diffusive oxygen uptake (DOU), dominant microbial process involved in carbon remineralization, bioturbation rate $\left(D_{b}\right)$.

\begin{tabular}{|c|c|c|c|c|c|}
\hline \multirow[b]{2}{*}{ Stations } & \multicolumn{2}{|c|}{ Prodelta area } & \multicolumn{3}{|c|}{ Shelf area } \\
\hline & $\mathrm{A}$ & $\mathrm{B}$ & $\mathrm{C}$ & 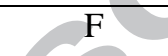 & $\mathrm{J}$ \\
\hline Latitude $\left({ }^{\circ} \mathrm{N}\right)$ & $43^{\circ} 18^{\prime} 752$ & $43^{\circ} 18^{\prime} 175$ & $43^{\circ} 16^{\prime} 405$ & $43^{\circ} 10^{\prime} 01$ & $43^{\circ} 16^{\prime} 11$ \\
\hline Longitude $\left({ }^{\circ} \mathrm{E}\right)$ & $4^{\circ} 51^{\prime} 109$ & $4^{\circ} 50^{\prime} 135$ & $4^{\circ} 46^{\prime} 632$ & $4^{\circ} 38^{\prime} 98$ & $4^{\circ} 58^{\prime} 11$ \\
\hline Depth (m) & 25 & 56 & 76 & 78 & 86 \\
\hline Distance $(\mathrm{km})$ & 1.9 & 3.0 & 8.6 & 21.6 & 12.1 \\
\hline$\omega^{\mathrm{a}}$ & 10 & 2.0 & 0.5 & 0.1 & 0.1 \\
\hline $\begin{array}{l}\text { Degradation } \\
\text { pigments }(\%)^{\mathrm{b}}\end{array}$ & $67.7 \pm 0.5$ & $81.4 \pm 0.9$ & $88.1 \pm 0.5$ & $89.2 \pm 1.5$ & $92.1 \pm 0.5$ \\
\hline$\delta^{13} \mathrm{C}_{\mathrm{OC}}^{\mathrm{b}}$ & -27.2 & & -25.4 & -24.2 & -24.3 \\
\hline $\operatorname{RPD}(\mathrm{cm})^{\mathrm{c}}$ & 0.5 & & 1 & 3 & 4 \\
\hline $\mathrm{OPD}(\mathrm{mm})^{\mathrm{d}}$ & $1.4 \pm 0.2$ & $2.2 \pm 0.3$ & $4.7 \pm 1.5$ & $9.7 \pm 2.1$ & $7.5 \pm 2.2$ \\
\hline $\operatorname{DOU}\left(\mathrm{mmol} / \mathrm{m}^{-2} / \mathrm{a}\right)^{\mathrm{d}}$ & $21.5 \pm 3.9$ & $15.7 \pm 2.1$ & $10.3 \pm 3.2$ & $5.3 \pm 0.7$ & $7.2 \pm 3.3$ \\
\hline $\begin{array}{l}\text { Dominant microb } \\
\text { process }^{\mathrm{a}}\end{array}$ & Anoxic & Oxic & Oxic & Oxic & Oxic $\approx$ Anoxic \\
\hline$D_{b}\left(\mathrm{~cm}^{2} / \mathrm{a}\right)^{\mathrm{a}}$ & 0.5 & 2.0 & 10 & 10 & 10 \\
\hline
\end{tabular}




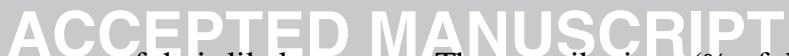

Table 2. Principal lipid biomarkers used in this study and a summary of their likely sources. The contributions (\% of the total fatty acids) of these different markers are given for potential Mediterranean sources. MC-SAFAs: Mid-chain even-number saturated fatty acids, LC-SAFAs: Long-chain saturated fatty acids, PUFAs: polyunsaturated fatty acids, MUFA: monounsaturated fatty acid.

\begin{tabular}{|c|c|c|c|c|c|c|c|c|}
\hline \multirow[b]{2}{*}{ Fatty acids } & \multicolumn{6}{|c|}{ SELECTED MEDITERRANEAN SOURCES } & \multirow[b]{2}{*}{ Assignment } & \multirow[b]{2}{*}{ References } \\
\hline & River $\mathrm{SOM}^{\mathrm{a}}$ & Macrodetritus & Oak leaves ${ }^{\dagger}$ & Duckweeds $^{\dagger}$ & Copepods $^{¥}$ & Skeletonema sp. ${ }^{\mathrm{b}}$ & & \\
\hline MC-SAFAs $\left(<\mathrm{C}_{20}\right)$ & 36.3 & 23.1 & 25.8 & 21.6 & 45.2 & 36.2 & $\begin{array}{l}\text { Non specific, but shorter } \\
\text { chains predominate in } \\
\text { phytoplankton }\end{array}$ & 1,2 \\
\hline $\mathrm{C}_{16}+\mathrm{C}_{18}$ & 31.7 & 19.6 & 21.2 & 19.8 & 43.9 & 13.0 & $\begin{array}{l}\text { High amounts in } \\
\text { invertebrates }\end{array}$ & 3 \\
\hline LC-SAFAs $\left(>\mathrm{C}_{20}\right)$ & 24.4 & 50.7 & 33.9 & 10.3 & 0.0 & 0.0 & Terrestrial higher plants & $3-6$ \\
\hline $\mathrm{C}_{20-23}$ & 10.1 & 15.9 & 9.3 & 3.7 & & 7 & & \\
\hline $\mathrm{C}_{24-30}$ & 14.3 & 34.8 & 24.6 & 6.6 & & & & \\
\hline 24:0/(22:0+26:0) & 0.7 & 0.6 & 0.4 & 1.1 & - & - & $\begin{array}{c}<0.67 \text { if } \mathrm{C} 3 \text { plants } \\
\text { dominate over C4 plants }\end{array}$ & 7 \\
\hline $\mathrm{C}_{18}$ PUFAs $(18: 2 \omega 6$ and $18: 3 \omega 3)$ & 3.9 & 6.3 & 19.0 & 56.8 & & 1.6 & Terrestrial higher plants & 8 \\
\hline 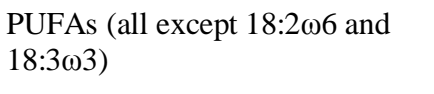 & $\begin{array}{c}2.5 \\
(\mathrm{EPA}=0.8)\end{array}$ & $\begin{array}{c}1.5 \\
(\mathrm{EPA}=0.5)\end{array}$ & 0.1 & $\begin{array}{c}2.0 \\
(\mathrm{EPA}=1.1)\end{array}$ & $\begin{array}{c}38.8 \\
(\mathrm{EPA}=8.4)\end{array}$ & $\begin{array}{c}26.9 \\
(\mathrm{EPA}=14.4)\end{array}$ & $\begin{array}{l}\text { Phytoplankton (with EPA } \\
\text { specific to diatoms) }\end{array}$ & 1,9 \\
\hline MUFA; $16: 1 \omega 7$ & 8.7 & 2.1 & 0.7 & 2.8 & 7.3 & 21.0 & $\begin{array}{c}\text { Common in diatoms and } \\
\text { bacteria }\end{array}$ & 1,10 \\
\hline $\begin{array}{l}\text { Branched iso- and anteiso-, odd- } \\
\text { number } \mathrm{C}_{15} \text { and 18:1 } 107\end{array}$ & 15.5 & 8.0 & & 2.2 & 6.0 & 3.8 & Bacterial sources & 10 \\
\hline
\end{tabular}

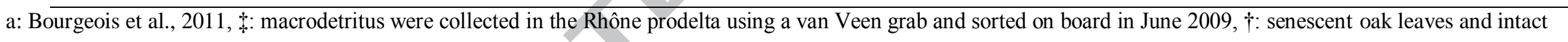

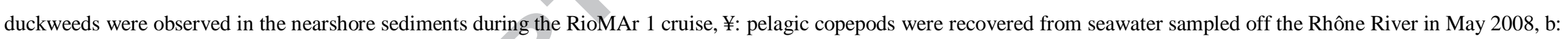
Nahon et al., 2010.

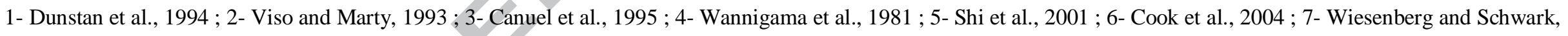
2006 ; 8- Budge et al., 2001; 9- Mansour et al., 1999; 10- Mrozik et al., 2014. 
Table 3. First order degradation constant $(\mathrm{k})$ for the total fatty acids ( $\Sigma F A s)$ and some compounds of interest (a ${ }^{-1}$ ). Terr PUFAs:

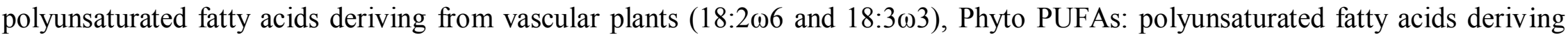
from phytoplankton (all minus Terr PUFAs). Deviations between modeled and measured concentrations were quantified as \% standard deviation (Niggemann and Schubert, 2006). The proportion of the non-reactive pool $\left(\mathrm{C}_{r e f}\right)$ is shown in brackets (see Section 2.5 for an explanation of model parameters).

\begin{tabular}{|c|c|c|c|c|c|c|c|}
\hline & & $\Sigma F A s$ & $16: 0$ & $24: 0$ & $26: 0$ & Terr PUFAs & Phyto PUFAs \\
\hline \multirow{3}{*}{$\frac{\frac{4}{Q}}{\frac{\pi}{\sigma}}$} & Station C & $34^{\mathrm{a}}[28 \%]$ & $58^{\mathrm{a}}[21 \%]$ & $44^{\mathrm{a}}[54 \%]$ & nd & $82^{\mathrm{a}}[24 \%]$ & $20^{\mathrm{b}}[12 \%]$ \\
\hline & Station F & $80^{\mathrm{b}} \quad[12 \%]$ & $130^{\mathrm{b}}[11 \%]$ & $131^{\mathrm{a}}[24 \%]$ & $33^{\mathrm{b}}[25 \%]$ & $115^{\mathrm{b}}[4 \%]$ & $60^{\mathrm{b}}[4 \%]$ \\
\hline & Station J & $4^{\mathrm{b}}[50 \%]$ & $10^{\mathrm{a}}[52 \%]$ & $54^{\mathrm{a}}[70 \%]$ & nd & nd & $19^{\mathrm{b}}[13 \%]$ \\
\hline
\end{tabular}

${ }^{\mathrm{a}} 0-10 \%$ of deviation from observations, ${ }^{\mathrm{b}} 0-20 \%$, nd: no solution. 


\section{ACCEPTED MANUSCRIPT}

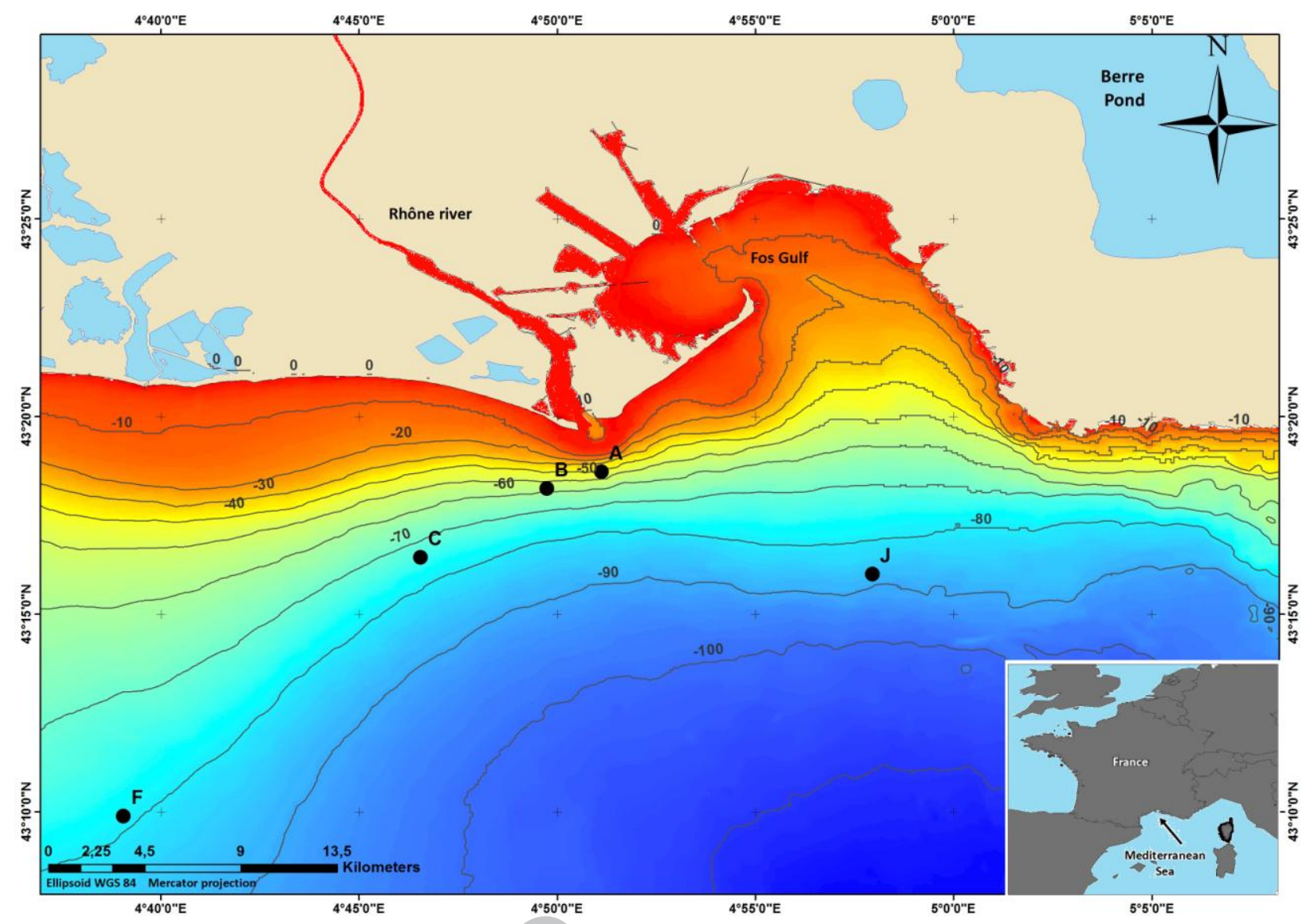



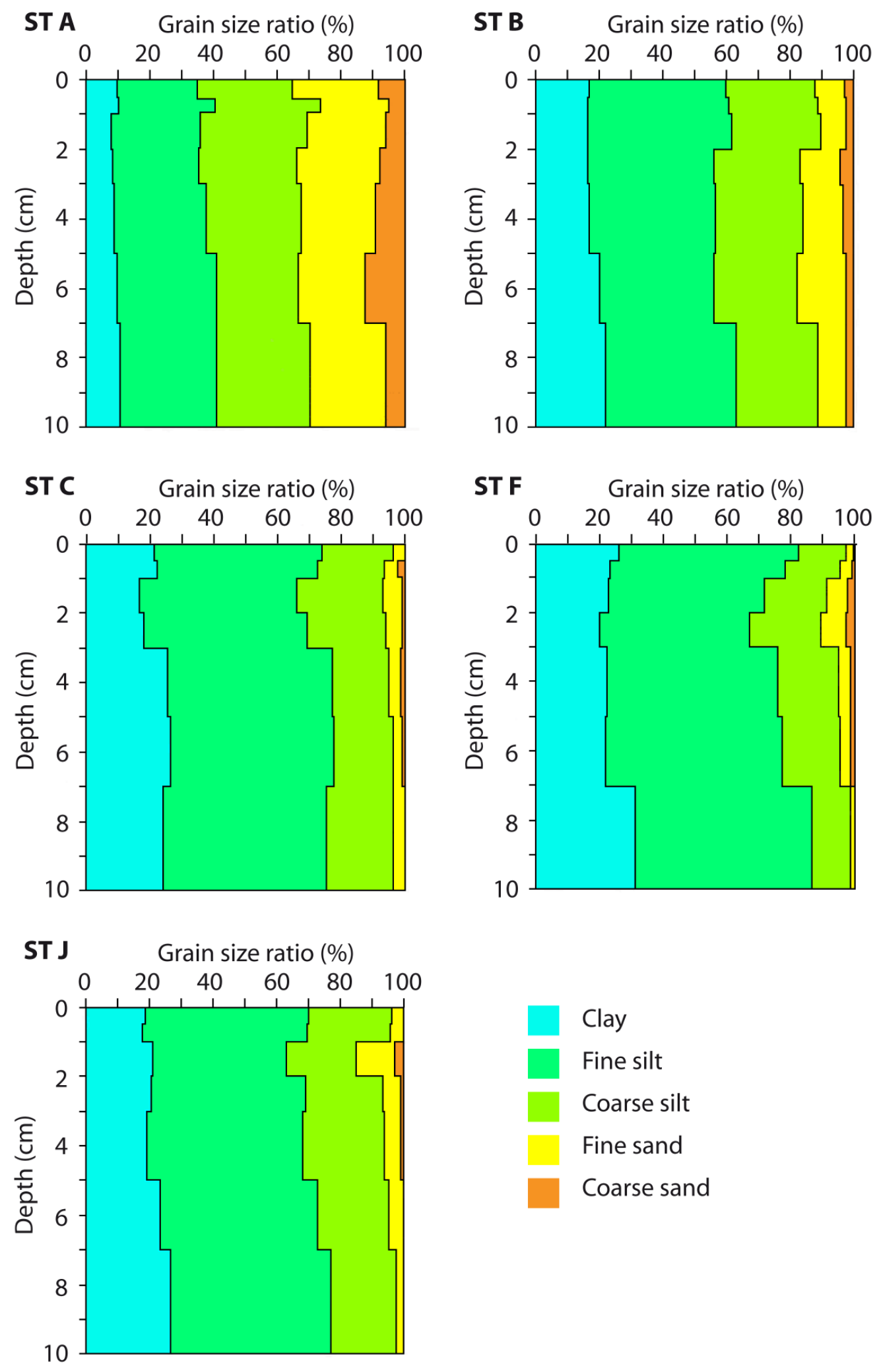

Clay

Fine silt

Coarse silt

Fine sand

Coarse sand 


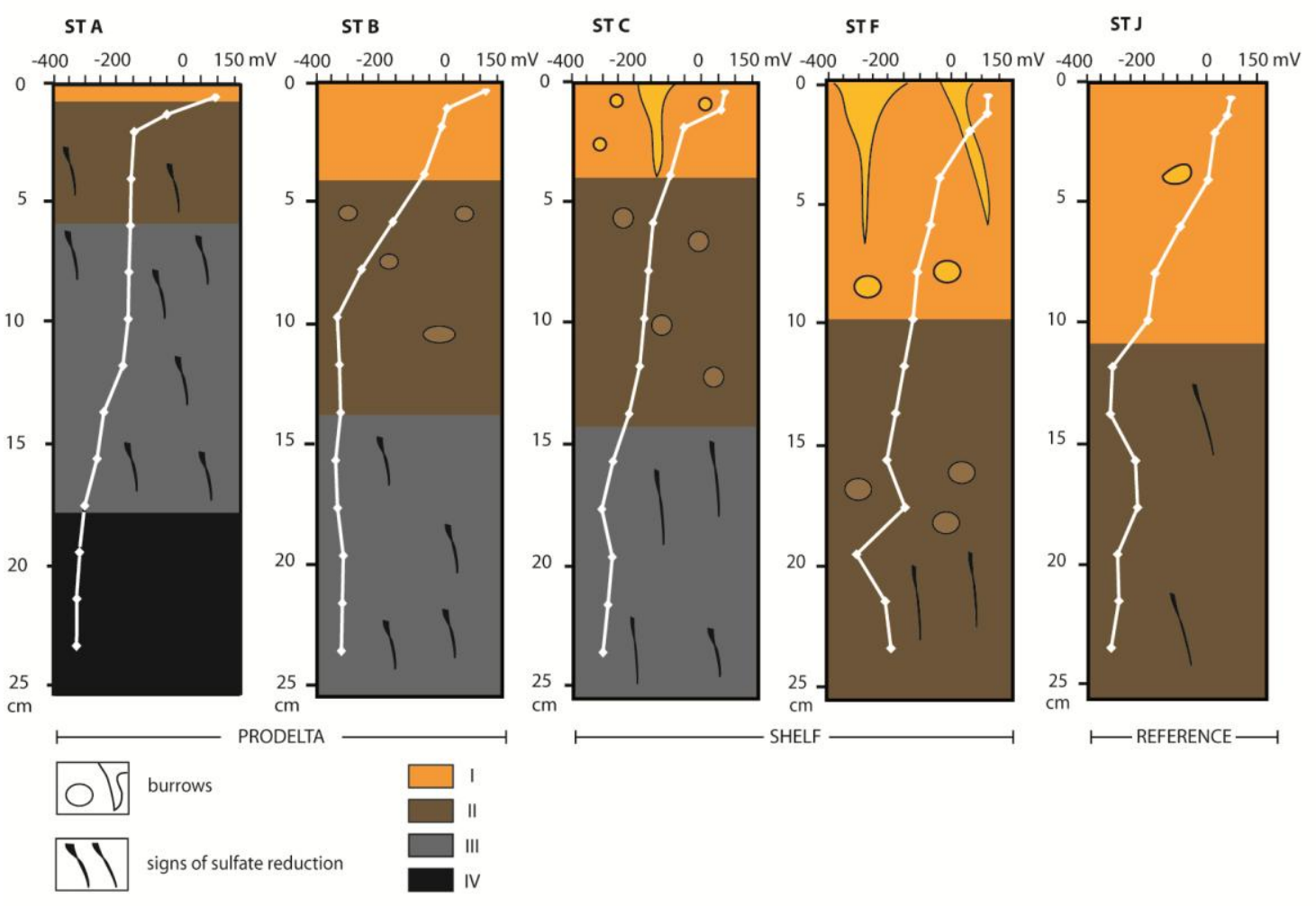




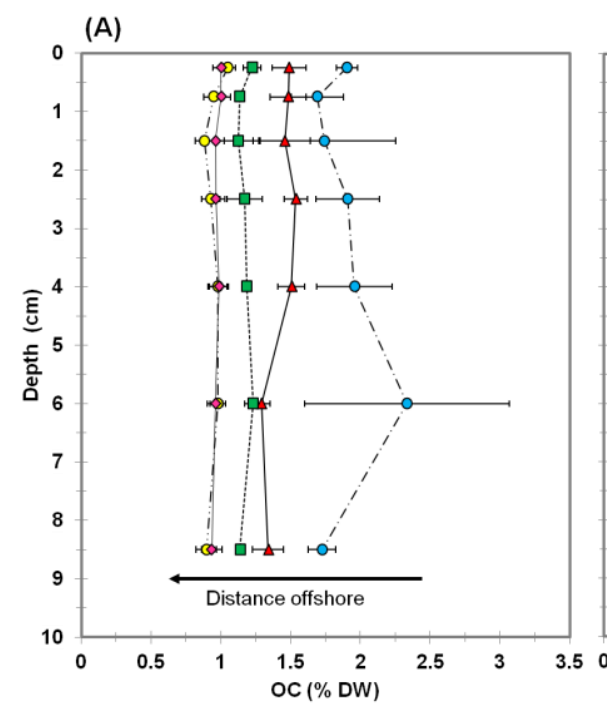

(B)

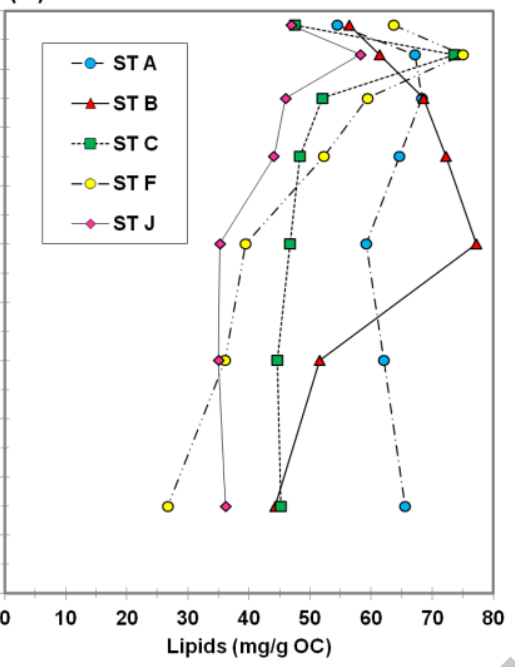

(C)

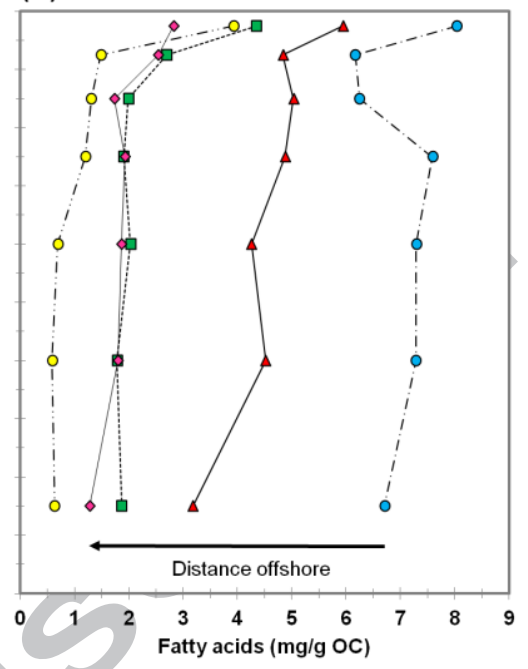


Height

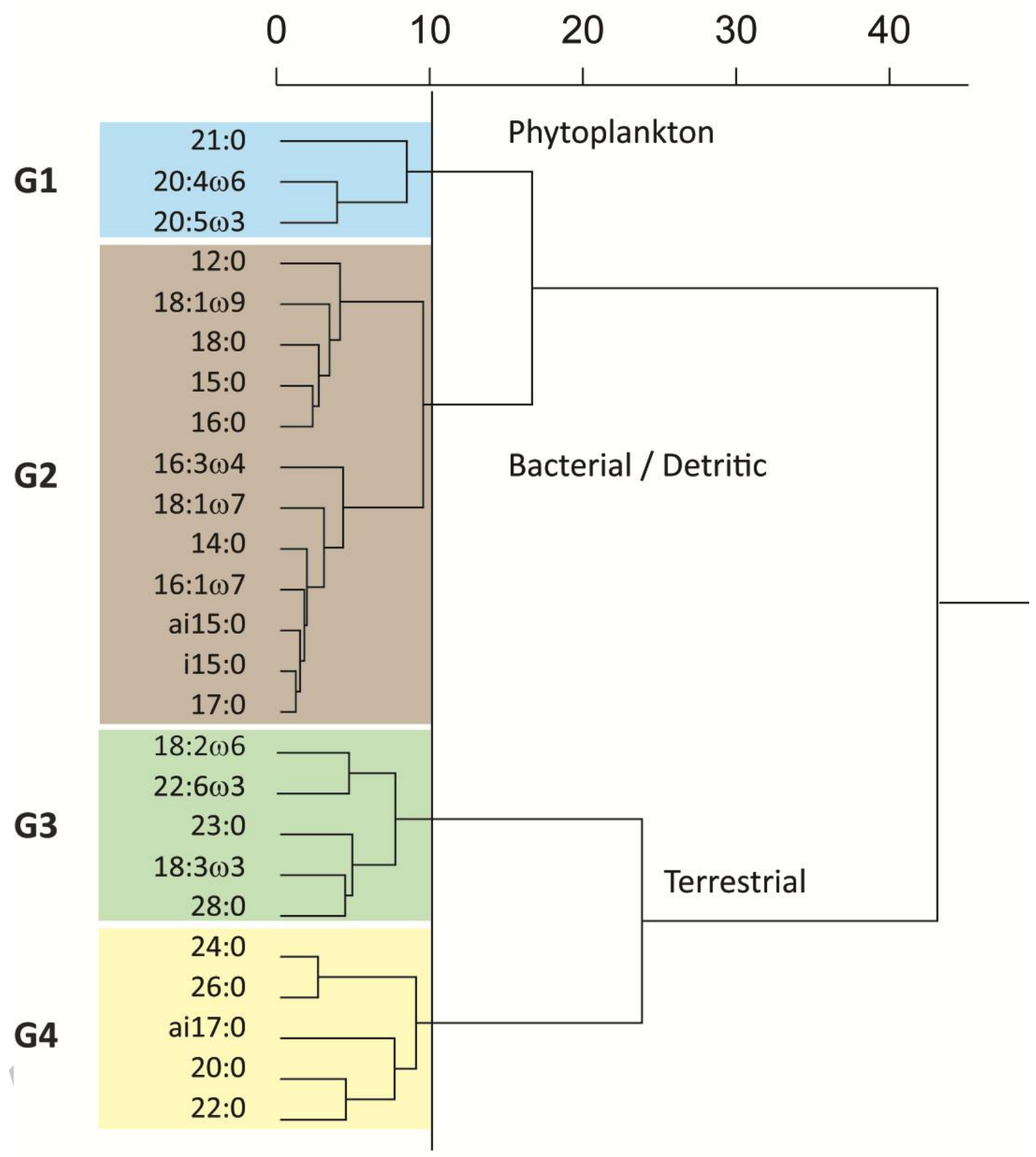


ST A

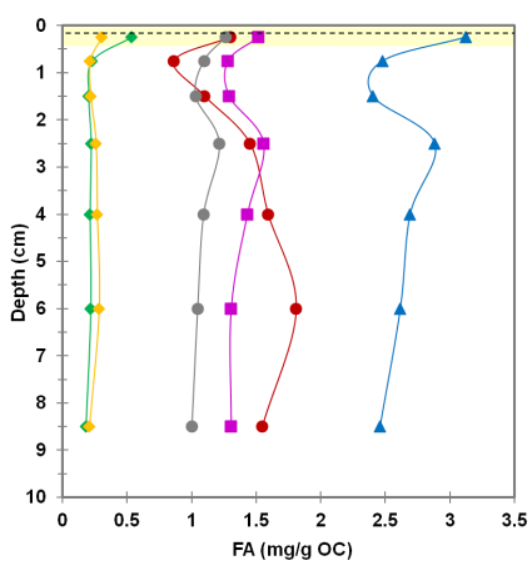

ST F

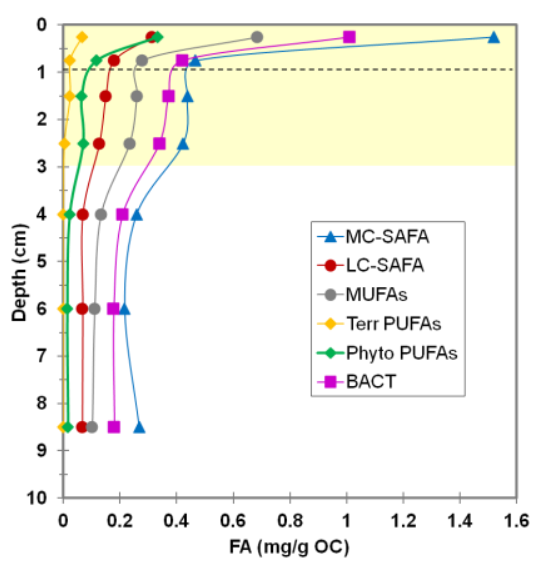

ST B

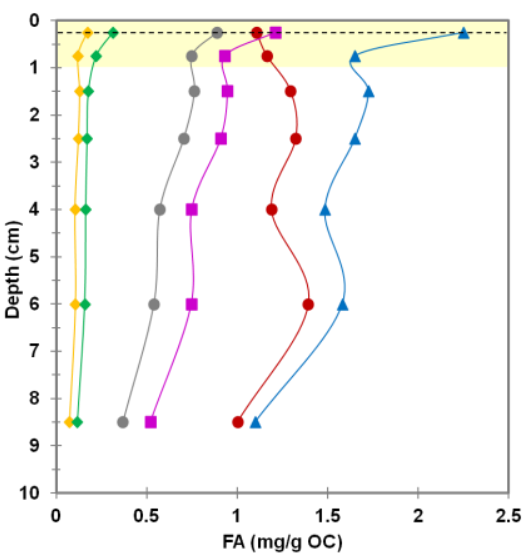

ST J

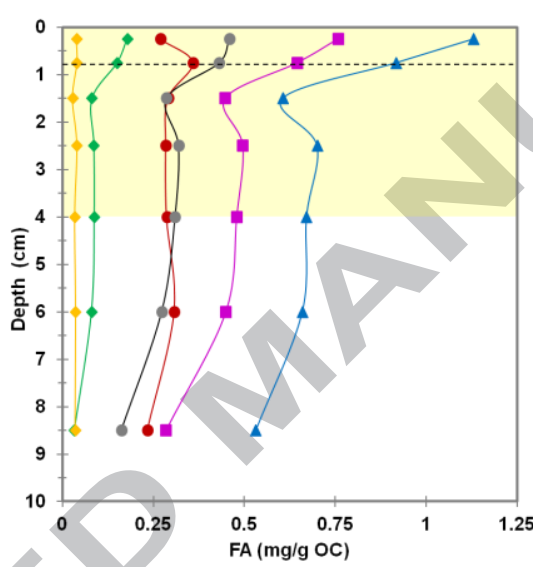

ST C

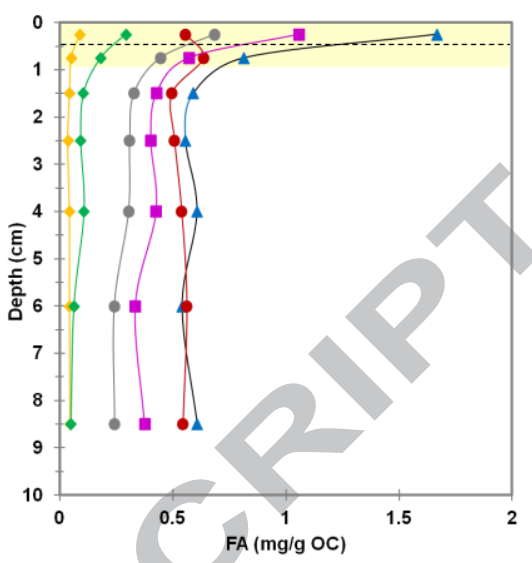

5 


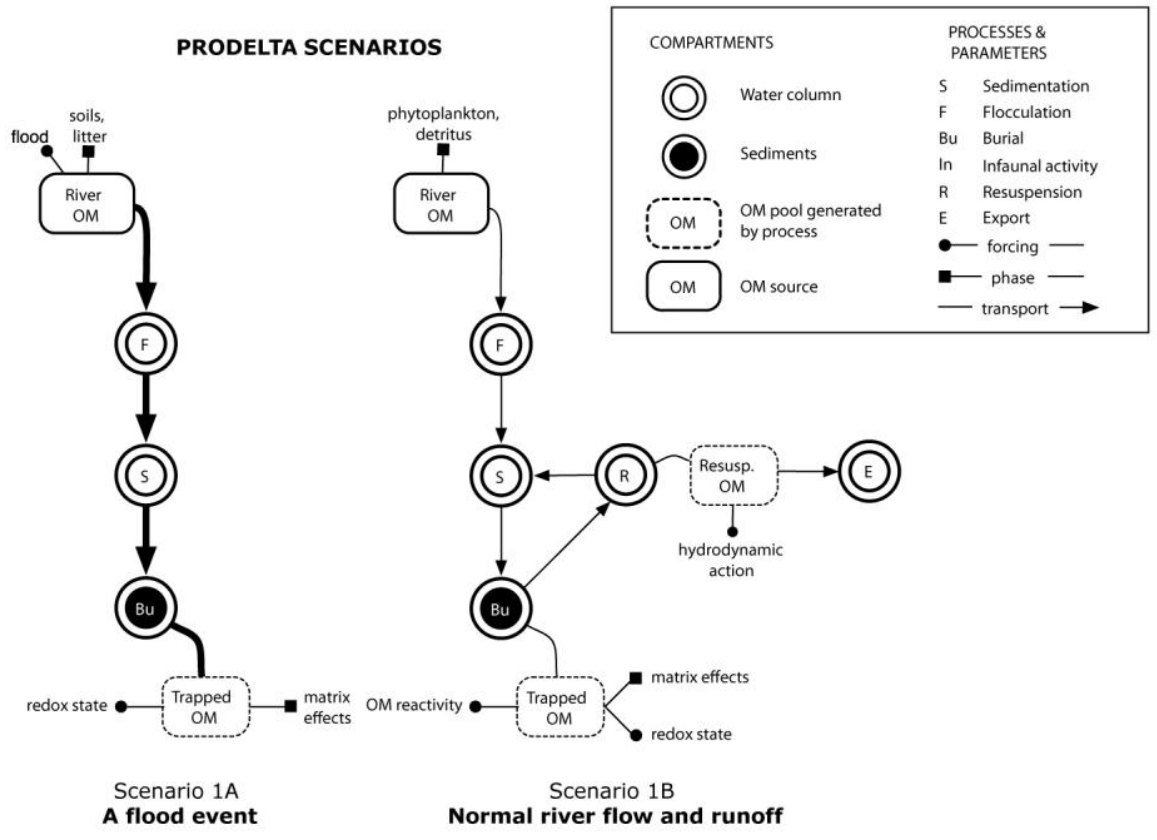

SHELF SCENARIO

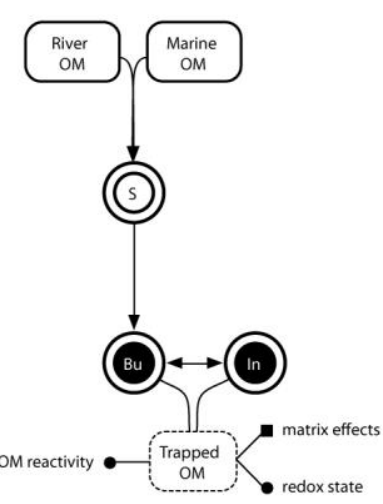

Scenario 2

Mixed origin of POM and

low sedimentation rates 
Graphical abstract

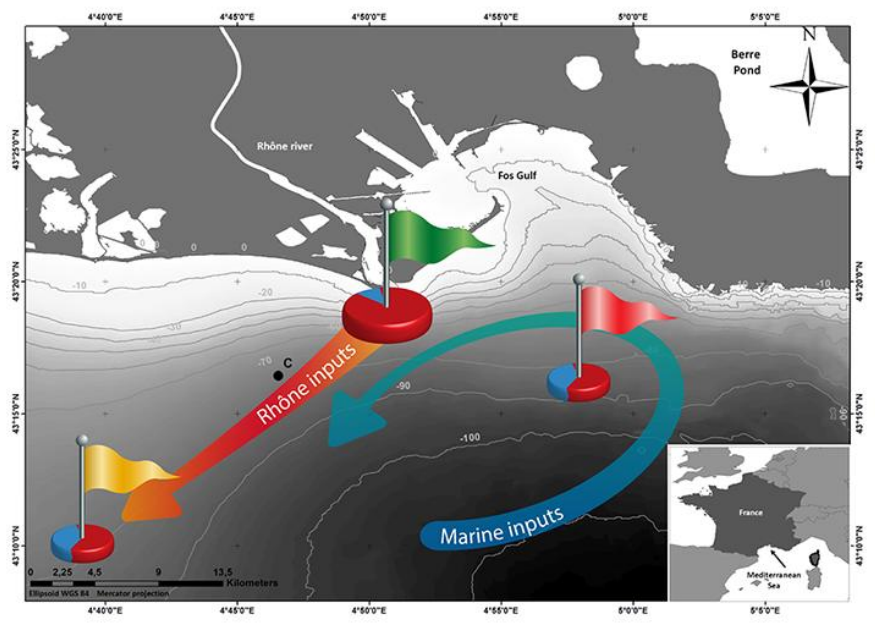

The size of the pie chart is indicative of the amount of particulate organic matter (OM) in the sediments.

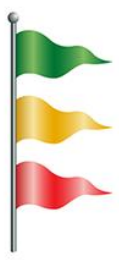

Recent and labile POM, efficient degradation

Mixture of labile and altered POM, enhanced degradation

Old and altered POM, low degradation

Marine OM
Terrestrial OM

stove $\left(\frac{10}{20}\right.$ 


\section{Highlights}

Organic matter degradation trends on a river-dominated coast were characterized Organic matter is mostly continental on the prodelta, and marine on the shelf Microbial decay of fatty acids from both sources is more efficient in the oxic layer

Fatty acid degradation scenarios are proposed for the Rhône river deltaic system Early diagenesis is constrained by OM quality, matrix, redox and depositional setting 